University of Nebraska - Lincoln

DigitalCommons@University of Nebraska - Lincoln

Publications from USDA-ARS / UNL Faculty

U.S. Department of Agriculture: Agricultural

Research Service, Lincoln, Nebraska

February 2008

\title{
Geochemistry in the modern soil survey program
}

\author{
M. A. Wilson \\ USDA-NRCS \\ R. Burt \\ USDA-NRCS \\ J. M. Scheyer \\ USDA-NRCS
}

A. B. Jenkins

USDA-NRCS

J. V. Chiaretti

USDA-NRCS

See next page for additional authors

Follow this and additional works at: https://digitalcommons.unl.edu/usdaarsfacpub

Part of the Agricultural Science Commons

Wilson, M. A.; Burt, R.; Scheyer, J. M.; Jenkins, A. B.; Chiaretti, J. V.; and Ulmer, M. G., "Geochemistry in the modern soil survey program" (2008). Publications from USDA-ARS / UNL Faculty. 223.

https://digitalcommons.unl.edu/usdaarsfacpub/223

This Article is brought to you for free and open access by the U.S. Department of Agriculture: Agricultural Research Service, Lincoln, Nebraska at DigitalCommons@University of Nebraska - Lincoln. It has been accepted for inclusion in Publications from USDA-ARS / UNL Faculty by an authorized administrator of DigitalCommons@University of Nebraska - Lincoln. 


\section{Authors}

M. A. Wilson, R. Burt, J. M. Scheyer, A. B. Jenkins, J. V. Chiaretti, and M. G. Ulmer 


\title{
Geochemistry in the modern soil survey program
}

\author{
M. A. Wilson • R. Burt • S. J. Indorante • \\ A. B. Jenkins • J. V. Chiaretti • M. G. Ulmer • \\ J. M. Scheyer
}

Received: 6 November 2006 / Accepted: 11 May 2007 / Published online: 11 July 2007

\begin{abstract}
Elemental analysis has played an important role in the characterization of soils since inception of the soil survey in the US. Recent efforts in analysis of trace and major elements (geochemistry) have provided necessary data to soil survey users in a variety of areas. The first part of this paper provides a brief overview of elemental sources, forms, mobility, and bioavailability; critical aspects important to users of soil survey geochemical data for appropriate use
\end{abstract}

M. A. Wilson $(\bowtie) \cdot$ R. Burt $\cdot$ J. M. Scheyer National Soil Survey Center, USDA-NRCS, 100 Centennial Mall N., Rm. 152, MS 41, Lincoln, NE 68508, USA

e-mail: mike.wilson@lin.usda.gov

\section{S. J. Indorante}

USDA-NRCS,

148 E. Pleasant Hill Road, Suite 105,

Carbondale, IL 62903, USA

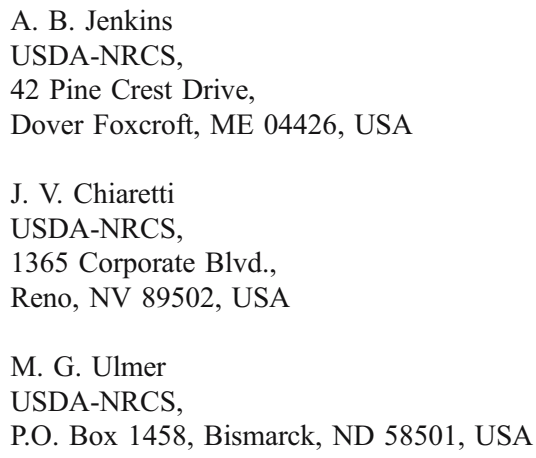

and interpretations. Examples are provided based on data gathered as part of the US soil survey program. The second part addresses the organization of sample collection in soil survey and how soil surveys are ideally suited as a sampling strategy for soil geochemical studies. Geochemistry is functional in characterization of soil types, determining soil processes, ecological evaluation, or issues related to soil quality and health, such as evaluating suitability of soils for urban or agricultural land use. Applications of geochemistry are on-going across the US and are documented herein. This analytical direction of soil survey complements historic efforts of the National Cooperative Soil Survey Program and addresses the increasing need of soil survey users for data that assists in understanding the influence of human activities on soil properties.

Keywords Trace elements · Soil survey · Pedology · Parent material $\cdot$ Anthropogenic

\section{Introduction}

Geochemistry is an evaluation of the distribution (species and concentration) of chemical elements in the biosphere (rock, soil, water, plants, and air) and includes the study of chemical processes and reactions that govern the composition of and chemical flux between various states (Kabata-Pendias and 
Pendias 2001; Neuendorf et al. 2005). Much of the current emphasis on geochemistry in soil science is related to the chemistry of trace elements controlling the movement, distribution, and fate in plants and soils of native pools and anthropogenic additions of elements (Roberts et al. 2005). Trace element is a general term for those elements that are regarded as having low concentration in soils or rocks. These elements exist as both cations (e.g., $\mathrm{Cu}, \mathrm{Zn}, \mathrm{Cd}, \mathrm{Cr}$, $\mathrm{Hg}, \mathrm{Ni}, \mathrm{Pb}$, and $\mathrm{Zn}$ ) and anions (e.g., As, Se, Mo, B). Focus in the past was typically on essentiality of these elements and many were regarded as micronutrients. There are 17 trace elements regarded as essential for plants based on their specific biochemical role (Kabata-Pendias and Pendias 2001). Today, understanding of the essentiality of elements is still important, but "trace" is somewhat a misnomer given that these elements may have relatively high natural concentrations in certain soils and with increased recognition of anthropogenic contamination (humaninduced additions of elements) to soils worldwide (Roberts et al. 2005). Patterns of natural soil variability provide the starting point for understanding and measuring differences between natural concentrations of elements and anthropogenic effects. A soil survey separates this natural variability into soil mapping units by application of the soil forming factor model (Jenny 1941) to the landscape. These factors are active in and responsible for the formation of soil at any given point on the landscape (SSSA 1997). Depending on the impact of landuse, human induced processes are also considered a factor of soil formation (Yaalon and Yaron 1966; Tugel et al. 2005).

A soil survey is defined as the systematic examination, description, classification, and mapping of soils in a designated geographic area (SSSA 1997). State and federal soil survey activities in the United States began in 1896 and have evolved into what is now called the "modern soil survey" (Indorante et al. 1996). Original small scale-colored maps were general in nature or were single purpose surveys like those made for conservation planning. With the formation of the National Cooperative Soil Survey (NCSS) in 1952, the "modern soil survey" era was born. This cooperative effort includes federal agencies such as the Natural Resources Conservation Service, Forest Service, Bureau of Indian Affairs, Bureau of Land Management, universities, and state and local agencies. The beginning of this era was marked by the publication of more detailed and more sophisticated soil surveys that were prepared on a photographic base. Soil Taxonomy (Soil Survey Staff 1975, 1999) was developed as the system for soil classification, and soil surveys and soil survey information were produced for multiple uses. The common disciplinary thread of soil survey, regardless of the era, is the study of soils or soil-landscapes in their natural settings. The fundamental purposes of a soil survey are to show geographic distribution of soils, provide data on properties of component soils, and to make predictions regarding landuse and management (Soil Survey Division Staff 1993). To this end, a soil survey includes soil maps, soil series descriptions, map unit descriptions, soil data, taxonomic classifications, and interpretations. The detail of the soil maps (scales commonly between 1:12,000 and $1: 24,000)$, and the detail of the supporting information provides an excellent foundation for trace element survey whether studying natural trace element variation or anthropogenic effects. Soil surveys also supply researchers with a high degree of sample stratification, which provides for a higher degree of accuracy and precision when compared to more general resource maps (e.g. landscape classification maps or surficial geology maps).

A common component of the US Soil Survey Program that has spanned the years has been the use of elemental analysis to provide information about soils and land use. Early studies (Brown and Byers 1935; Holmes et al. 1938) used geochemistry to study soil uniformity with depth and pedogenic processes such as mineral weathering, podzolization, and other eluviation/illuviation processes. Those publications, as well as Denison (1930), Byers et al. (1935), and Holmes (1928), used the composition and silica/ sesquioxide $(\mathrm{Si} / \mathrm{Al}+\mathrm{Fe})$ ratio of the colloidal fractions $(<1.0 \mu \mathrm{m})$ to define the property range for the series boundary of soils. Marbut (1935) defined Category V (Inorganic Colloid Composition Group) of the 1935 US Soil Classification System based on these types of data, and published elemental data from both the colloidal and $<2$-mm fractions to illustrate differences in soils from across the US.

Later emphasis on trace elements by USDA-Soil Conservation Service scientists within the Soil Survey Investigations Division was related to landuse. Joe Kubota (Alban and Kubota 1960; Kubota 1964; Kubota et al. 1961, 1967) studied elements such as 
Co and Mo in relation to soil and plant deficiencies or toxicities for animal production. George Holmgren led a study that analyzed the concentration of $\mathrm{Pb}, \mathrm{Cd}$, $\mathrm{Zn}, \mathrm{Cu}$, and $\mathrm{Ni}$ in agricultural soils across the U.S. (Holmgren et al. 1993). This final study is regarded as a primary source of elemental data on soils of the US.

Today, elemental data are being produced on samples collected as part of soil survey documentation across the US. These analyses were necessitated by the increasing demand for these data by soil survey clientele and soil scientists of the NCSS requiring information on native (background) concentrations of trace elements in soils (Wilson et al. 2002; Burt et al. 2003b). Soil survey is in a unique position to provide data on the complete spectrum of elemental distribution in soils as defined by extractable, exchangeable, soluble, and total forms, accompanied by associated laboratory characterization of physical, chemical and mineralogical properties, and site specific field data.

The evolution of both the modern soil survey (quantitative, multidisciplinary) and laboratory instrumentation (multi-elemental quantification) has resulted in complementary, synergistic convergence of these two aspects of science. This paper will discuss the utility of geochemistry in soil survey with the following objectives: (1) provide a brief overview of background information related to sources and bioavailability of trace elements in soils that affects elemental distribution from a pedological perspective; (2) describe how soil survey provides a logical structure for determining elemental distribution from natural sources over geographic areas; (3) discuss the need, utility, and application of geochemical data within the NCSS. These objectives will be discussed in two parts, addressing issues related to elemental distribution and reactivity in soils and the applicability of these data to soil survey, respectively.

\section{Materials and methods}

Data used as examples in this paper are taken from geochemistry data that are located on a geospatial website at: http://soils.usda.gov/survey/geochemistry/ index.html. The dataset represents horizons from 636 pedons (the smallest volume that can be called "a soil") representing component soil series from mapping units across the conterminous USA, Hawaii, and
Alaska (Fig. 1). Pedons were described and samples collected by standard soil survey procedures (Soil Survey Division Staff 1993; Burt 2004). Samples were sieved (stainless steel) to $<2-\mathrm{mm}$ and finely ground $(<150-\mu \mathrm{m})$ in a silicon nitride ball mill. The soil digestion for trace elements seals $0.50 \mathrm{~g}$ soil with $9 \mathrm{ml}$ concentrated $\mathrm{HNO}_{3}$ and $3 \mathrm{ml}$ concentrated $\mathrm{HCl}$ in a covered polypropylene vessel with microwave digestion at $175^{\circ} \mathrm{C}$ for $4.5 \mathrm{~min}$. The digested material was quantitatively transferred with reverse-osmosis, deionized water to a 50-ml final volume. Elemental analysis was determined by ICP-atomic emissions spectroscopy for all elements except $\mathrm{Hg}$, the analysis of which was performed with cold vapor hydride atomic absorption. Quality assurance samples (blank, duplicate, and certified reference material) were included for every 28 samples in the digestion process. Evaluation of standard reference material is described in Burt et al. (2003b).

Sites were classed as either anthropogenic-influenced or non-anthropogenic (natural) based on knowledge of likely trace element contamination by agricultural, military, industrial, or urban sources, providing a unique database for users. In this paper, surface mineral horizon data from the upper $50 \mathrm{~cm}$ was sorted into the two classes and plotted in histograms and cumulative frequency diagrams based on concentration ranges, and the mean and median calculated. A subset of 22 pedons was selected to represent soils with different lithologic sources and the median of horizons within each pedon and average absolute deviation from the median were calculated for $\mathrm{Ni}, \mathrm{Pb}$, and $\mathrm{Zn}$. Also, eight pedons from mapping units named for the Highsplint series from Fayette and Raleigh Counties, West Virginia were selected to examine how elements range across pedons in a single series. The Highsplint soil is

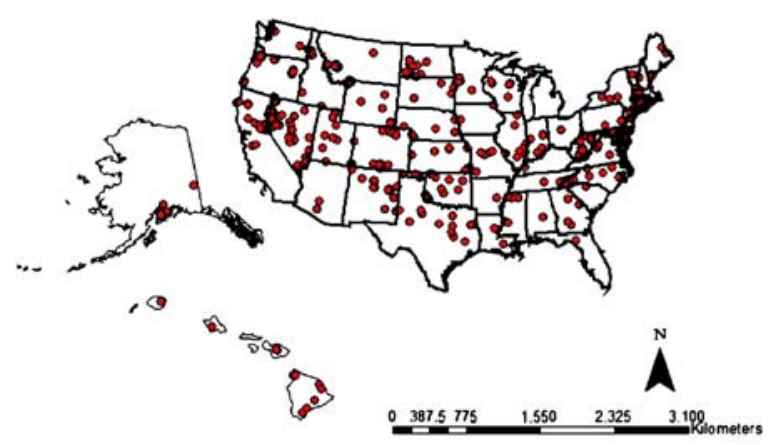

Fig. 1 Location of pedons with geochemistry data used 
extensive, developed from sedimentary geologic materials, and mapped in several states in the AlleghenyCumberland Plateau region of the US. These data were evaluated for differences between surface mineral (A horizon) and lower subsoil (BC horizon). The mean, median, and coefficient of variation for selected elements were calculated. Box and whisker plots were made for selected elements.

\section{Trace elements in soils}

\section{Parent materials}

Background or native concentration of an element in soil is related to the mineralogy of the parent material from which the soil has developed, modified by pedogenic processes. Trace elements in native forms occur in primary soil minerals as components of the mineral structure. For example, $\mathrm{Cu}, \mathrm{Co}, \mathrm{Pb}, \mathrm{Ni}$, and $\mathrm{Zn}$ are all present in a variety of silicate and aluminosilicate minerals such as olivines, amphiboles, micas, and feldspars. The wide variety of parent materials creates a range in soil trace element content of 2 to 3 orders of magnitude for many elements. Also, there are specific parent materials that have extremely high concentrations of selected elements (Table 1). For example, certain sedimentary deposits (organic rich coastal sediments and marls) are high in As due to presence of sulfidic materials (Chen et al. 2002; Gough et al. 1996) and geologic deposits rich in pyritic sulfur minerals contain enrichment of both As and Se (Strawn et al. 2002). Selected soils located on both coasts of the US are high in $\mathrm{Co}, \mathrm{Ni}$, and $\mathrm{Cr}$ due to formation (i.e. regolith derived) from extensive belts of metamorphic rocks composed of serpentine minerals (Rabenhorst and Foss 1981; Burt et al. 2001, Lee et al. 2001).

The median concentrations of $\mathrm{Ni}, \mathrm{Pb}$, and $\mathrm{Zn}$ for all horizons (surface and subsoil) from 22 pedons were summarized (Table 2) to illustrate this relationship. Geologic information (soil parent material) for Table 2 was derived from pedon descriptions. Soils are sorted by increasing $\mathrm{Ni}$ concentration and these data cover three orders of magnitude (2 to $2,400 \mathrm{mg} / \mathrm{kg}$ ), while $\mathrm{Pb}$ and $\mathrm{Zn}$ ranged from non-detectable to 52 and 6.4 to $220 \mathrm{mg} / \mathrm{kg}$, respectively (Table 2). Gypsiferous rock and eolian sand (Drygyp and Valentine soils, respectively) have low concentrations of these metals. Highest concentration of these three elements $(2,400 \mathrm{mg} / \mathrm{kg} \mathrm{Ni})$ was in the Serpentano pedon (serpentinite parent material), which also contained elevated concentrations of $\mathrm{Zn}(208 \mathrm{mg} / \mathrm{kg})$. The sequential order of parent materials relative to increasing concentrations of $\mathrm{Pb}$ and $\mathrm{Zn}$ is similar for both elements, though differs for Ni. This difference illustrates the variable composition of parent materials relative to elemental composition of each element. The range of values of these elements listed in Table 2 does not encompass the entire natural range, but are a reflection of selected soils in the dataset. For example, higher values of $\mathrm{Pb}$ and $\mathrm{Zn}(>1,000 \mathrm{mg} / \mathrm{kg})$ are found in soils derived from or contaminated by geologic materials with sulfide mineral inclusions (Pierzynski and Schwab 1993).

\section{Pedogenesis and redistribution}

Primary minerals derived from soil regolith undergo either congruent (dissolved, solution species are the only products) or incongruent (secondary mineral species are formed) dissolution during pedogenesis (Sposito 1989). These weathering products may undergo vertical and/or lateral redistribution as part of the biogeochemical cycle. Processes affecting trace element distribution within this cycle are important to understand and can be considered on scales that range from a single pedon to a watershed, ecosystem, or continent.

Plant uptake, leaching, runoff, erosion and gaseous losses are all possible pathways for elemental redistribution. Soil moisture and temperature are drivers for pedogenesis and influence elemental distribution ranging from accumulation of elements (e.g. $\mathrm{Ca}, \mathrm{Mg}$, $\mathrm{Na}, \mathrm{B}, \mathrm{Se}, \mathrm{Mo}$ ) in specific landscape positions of arid region soils to depletion of many trace and major elements in tropical region soils. For example, Marques et al. (2004) found that tropical soils on old (late Cretaceous) geomorphic surfaces of the Central Plateau of Brazil were enriched in elements with a valence of 3 or more (Ti, Zr, Th, Cr, La, V), attributable to the presence in resistant minerals or incorporation in secondary minerals such as Fe oxides, kaolinite, or gibbsite. Divalent elements such as Co, $\mathrm{Ni}, \mathrm{Cu}$, and $\mathrm{Zn}$ were depleted due to weak adsorption on oxides and organic matter in these acidic soils.

Vertical or lateral movement related to soil hydrology and/or redoximorphic conditions can result in trace element mobility as aqueous forms or as translocated, 
Table 1 Characteristics of selected trace elements in soils

\begin{tabular}{|c|c|c|c|c|c|}
\hline Element & $\begin{array}{l}\text { Ionic } \\
\text { Form }\end{array}$ & $\begin{array}{l}\text { Parent materials } \\
\text { with high concentrations } \\
\text { of the element }\end{array}$ & General reactivity in soils & Mobility & Sources of pollution \\
\hline As & $\begin{array}{l}\text { As } \\
\text { (III) } \\
\text { orAs } \\
(\mathrm{V})\end{array}$ & $\begin{array}{l}\text { Sedimentary materials rich } \\
\text { in sulfides (e.g.,coal } \\
\text { containing arsenopyrite, } \\
\text { organic rich coastal } \\
\text { sediments); sulfides of } \\
\text { ores of } \mathrm{Ag}, \mathrm{Pb}, \mathrm{Cu}, \mathrm{Ni} \text {, } \\
\text { etc. (Liao et al. 2005; Fio } \\
\text { et al. 1991) }\end{array}$ & $\begin{array}{l}\text { As released from sulfides } \\
\text { by oxidation; as released } \\
\text { is adsorbed by oxides and } \\
\text { organic matter and maybe } \\
\text { bound by precipitation } \\
\text { with } \mathrm{Al}, \mathrm{Fe}, \mathrm{Ca} \text {, and } \mathrm{Mg} \\
\text { (Huang and Fujii 1996). } \\
\text { Aqueous species include } \\
\mathrm{H}_{2} \mathrm{AsO}- \\
\left.\mathrm{As}_{4}, \mathrm{HAH}\right)_{2}^{0} \text { (Huang and } \\
\mathrm{Fujii} 1996) \text {. As }{ }^{5+} \text { is the } \\
\text { stable oxidation state in } \\
\text { aerated soils (Yang et al. } \\
\text { 2002) }\end{array}$ & $\begin{array}{l}\text { Generally considered } \\
\text { mobile. May be retained } \\
\text { or possibly transported } \\
\text { via organic and inorganic } \\
\text { soluble forms in water }\end{array}$ & $\begin{array}{l}\text { Wood preservative, } \\
\text { pesticides, coal burning, } \\
\text { mining/smelting, milling }\end{array}$ \\
\hline $\mathrm{Cd}$ & $\begin{array}{l}\mathrm{Cd} \\
\quad \text { (II) }\end{array}$ & $\begin{array}{l}\text { Similar geochemistry to } \\
\mathrm{Zn} \text { and often found in } \\
\text { association with } \mathrm{Zn} \\
\text { deposits. Low } \\
\text { concentration in } \\
\text { magmatic and most } \\
\text { sedimentary rocks, but } \\
\text { higher in argillaceous or } \\
\text { shales materials (Kabata- } \\
\text { Pendias and Pendias } \\
\text { 2001) }\end{array}$ & $\begin{array}{l}\text { Solution actitvity strongly } \\
\text { related to pH (Kabata- } \\
\text { Pendias and Pendias } \\
\text { 2001). Adsorption } \\
\text { increases with increases in } \\
\text { OM, sesquioxides, clay, } \\
\text { pH (Romkens and } \\
\text { Salomons 1998); } \\
\text { adsorption to carbonates } \\
\text { (Renella et al. 2004); } \\
\text { forms soluble complexes } \\
\text { of CdSO }, \text { CdCl' in } \\
\text { saline soils (Sposito 1989; } \\
\text { Suave and Parker 2005); } \\
\text { extremely toxic and no } \\
\text { known function in } \\
\text { biological processes } \\
\text { (Renella et al. 2004) }\end{array}$ & $\begin{array}{l}\text { Considered more mobile } \\
\text { that other heavy metals } \\
\text { (Renella et al. 2004). } \\
\text { Highest mobility at } \\
\text { pH } 4.5-5.5 \text {; relatively } \\
\text { immobile in alkaline soils } \\
\text { (Kabata-Pendias and } \\
\text { Pendias 2001) }\end{array}$ & $\begin{array}{l}\text { Air pollution; metal plating } \\
\text { and other industrial/ } \\
\text { municipal wastes } \\
\text { (Amacher 1996). } \\
\text { Phosphatic fertilizers; } \\
\text { sewage sludge (Renella } \\
\text { et al. 2004); Zn mining } \\
\text { and smelting }\end{array}$ \\
\hline $\mathrm{Cr}$ & $\begin{array}{l}\mathrm{Cr} \\
\text { (III) } \\
\text { or } \\
\mathrm{Cr} \\
\text { (VI) }\end{array}$ & $\begin{array}{l}\text { Ultramafic rocks or those } \\
\text { formations that have } \\
\text { undergone low grade } \\
\text { metamorphism, or } \\
\text { serpentinites (Burt et al. } \\
\text { 2001) }\end{array}$ & $\begin{array}{l}\text { Cr may exist as both } \\
\text { valence states in a soil. } \mathrm{Cr} \\
\text { (III) remains in cationic } \\
\text { form at most soil pHs and } \\
\text { has very low solubility } \\
\text { (precipited as hydroxides } \\
\text { at } \mathrm{pH}>4.5 \text { e.g., } \mathrm{Cr}(\mathrm{OH}) \text { or } \\
\mathrm{Cr}(\mathrm{OH})_{3} \text { or } \mathrm{Cr}_{2} \mathrm{O}_{3} \text {; } \\
\text { forms both soluble and } \\
\text { insoluble complexes with } \\
\text { organics and minerals). } \\
\text { Cr(VI) exists in soils as } \\
\text { anionic form similar to } \\
\text { orthophosphate or sulfate } \\
\text { and the chromate anion } \\
\text { may be adsorbed by } \\
\text { oxides or precipated by } \\
\text { cations (Bartlett and } \\
\text { James 1996) }\end{array}$ & $\begin{array}{l}\text { Generally immobile; most } \\
\text { soil } \mathrm{Cr} \text { is } \mathrm{Cr}^{3+} \text {, which } \\
\text { tightly binds to both } \\
\text { organic and inorganic } \\
\text { materials, } \mathrm{Cr}^{6+} \text { is much } \\
\text { more mobile (Suave and } \\
\text { Parker 2005). Cr in water } \\
\text { is as Cr } \mathrm{Cr}^{6+} \text { or colloidal, } \\
\text { organically-bound } \mathrm{Cr}^{3+} \\
\text { (Bartlett and James } 1996 \text { ) }\end{array}$ & $\begin{array}{l}\text { In diverse industrial wastes, } \\
\text { metal finishing/plating/ } \\
\text { electronics, wood treatment } \\
\text { (Förstner, 1995) }\end{array}$ \\
\hline
\end{tabular}


Table 1 (continued)

\begin{tabular}{|c|c|c|c|c|c|}
\hline Element & $\begin{array}{l}\text { Ionic } \\
\text { Form }\end{array}$ & $\begin{array}{l}\text { Parent materials } \\
\text { with high concentrations } \\
\text { of the element }\end{array}$ & General reactivity in soils & Mobility & Sources of pollution \\
\hline $\mathrm{Cu}$ & $\begin{array}{l}\mathrm{Cu} \\
\text { (II) }\end{array}$ & $\begin{array}{l}\text { Soils forming from } \mathrm{Cu} \\
\text { mineral deposits rare. } \\
\text { Geological ore deposits } \\
\text { containing minerals with } \\
\mathrm{Cu} \text { in association with } \mathrm{Fe} \\
\text { and S. Most abundant in } \\
\text { mafic and intermediant } \\
\text { rocks; excluded from } \\
\text { carbonate rocks (Kabata- } \\
\text { Pendias and Pendias } \\
\text { 2001) }\end{array}$ & $\begin{array}{l}\text { Specific adsorption by } \\
\text { carbonates, clays, oxides, } \\
\text { and organic matter } \\
\text { (Romkens and Salomons } \\
\text { 1998; Reed and Martens } \\
\text { 1996); may be present as } \\
\text { exchangeable cation } \\
\text { (Reed and Martens 1996); } \\
\text { adsorption involving } \\
\text { exchange sites in acid soil } \\
\text { conditions, chemisorption } \\
\text { with organic ligands in } \\
\text { alkaline conditions } \\
\text { (Kabata-Pendias and } \\
\text { Pendias 2001). }\end{array}$ & $\begin{array}{l}\text { Generally non-mobile due } \\
\text { to adsorption on organic } \\
\text { and mineral surfaces, but } \\
\text { biocycling results in } \\
\text { increasing surface } \\
\text { concentrations (Reed and } \\
\text { Martens } 1996, \text { Kabata- } \\
\text { Pendias and Pendias } \\
\text { 2001) }\end{array}$ & $\begin{array}{l}\text { Municipal sludge, waste } \\
\text { from smelting, poultry, } \\
\text { and swine manure (Reed } \\
\text { and Martens 1996) }\end{array}$ \\
\hline $\mathrm{Hg}$ & $\begin{array}{l}\mathrm{Hg} \\
\text { (O), } \\
\mathrm{Hg} \\
\text { (II) }\end{array}$ & $\begin{array}{l}\text { Low in most geologic } \\
\text { materials, but higher } \\
\text { concentrations when } \\
\text { sulfides present in rocks, } \\
\text { e.g., shales; present as a } \\
\text { sulfide mineral, cinnabar } \\
\text { (HgS), and associated } \\
\text { with other sulfide } \\
\text { minerals containing As, } \\
\mathrm{Se}, \mathrm{Ag}, \mathrm{Au}, \mathrm{Zn}, \mathrm{Pb} \\
\text { (Crock 1996) }\end{array}$ & $\begin{array}{l}\text { Very strong bonds with } \\
\text { S, either as inorganic } \\
\text { (forming HgS) or } \\
\text { organic (organic matter) } \\
\text { complexes, also } \\
\text { adsorption, or } \\
\text { complexed, soluble } \\
\text { forms of Hg by oxides } \\
\text { and clays (Crock 1996). } \\
\text { Precipitation as } \\
\text { hydroxide or carbonate } \\
\text { in alkaline soil, as sulfide, } \\
\text { or elemental mercury in } \\
\text { acid, reducing soils } \\
\text { (Crock 1996) }\end{array}$ & $\begin{array}{l}\text { Strong adsorption by } \\
\text { organic matter (in acid } \\
\text { soils) renders it relatively } \\
\text { immoble; accumulation } \\
\text { at soil surface. In alkaline } \\
\text { soils, most adsorption } \\
\text { by Fe oxides }\end{array}$ & $\begin{array}{l}\text { Combustion of fossil fuels } \\
\text { and volcanic activity; } \\
\text { sewage sludge, } \\
\text { agricultural input from } \\
\text { sterilizers, treated seeds: } \\
\text { also industrial input; } \\
\text { general widespread } \\
\text { occurance of element in } \\
\text { food chain (Crock 1996) }\end{array}$ \\
\hline $\mathrm{Ni}$ & $\mathrm{Ni}(\mathrm{II})$ & $\begin{array}{l}\text { Ultramafic rocks or those } \\
\text { formations that have } \\
\text { undergone low grade } \\
\text { metamorphism, or } \\
\text { serpentinites (Burt } \\
\text { et al. 2001) }\end{array}$ & $\begin{array}{l}\text { Organic complexes, or } \\
\text { soluble complexes with } \\
\text { sulfate, bicarbonate, } \\
\text { carbonate (Sposito 1989) }\end{array}$ & $\begin{array}{l}\text { Function as exchangeable } \\
\text { cation and bound by } \\
\text { oxides. Mobile under } \\
\text { reducing conditions } \\
\text { (Lee et al. 2001) }\end{array}$ & Mining, smelting, industrial \\
\hline $\mathrm{Pb}$ & $\mathrm{Pb}(\mathrm{II})$ & $\begin{array}{l}\text { Low in most geologic } \\
\text { materials, but higher } \\
\text { concentrations when } \\
\text { sulfides present in rock. } \\
\text { Ore deposits high in } \\
\text { sulfide minerals (PbS, } \\
\text { galena) }\end{array}$ & $\begin{array}{l}\text { Can form dissolved and } \\
\text { colloidal organometallic } \\
\text { compounds; organic } \\
\text { complexes, or soluble } \\
\text { complexes with sulfate, } \\
\text { bicarbonate, carbonate } \\
\text { (Sposito 1989) }\end{array}$ & $\begin{array}{l}\text { Generally considered } \\
\text { non-mobile, but limited } \\
\text { mobility demonstrated } \\
\text { in Norway (Steinnes } \\
\text { et al. 2005) }\end{array}$ & $\begin{array}{l}\text { Automotive; long-range } \\
\text { athmospheric transport } \\
\text { (Steinnes et al. 2005), } \\
\text { paint }\end{array}$ \\
\hline $\mathrm{Se}$ & $\begin{array}{l}\mathrm{Se}(0), \\
\mathrm{Se} \\
(\mathrm{II}), \\
\mathrm{Se} \\
(\mathrm{IV}), \\
\mathrm{Se} \\
(\mathrm{VI})\end{array}$ & $\begin{array}{l}\text { Upper Cretaceous and } \\
\text { Tertiary-aged marine } \\
\text { sedimentary deposits }\end{array}$ & $\begin{array}{l}\text { Microbial activity and } \\
\text { redox reactions affect } \\
\text { species; mobility and } \\
\text { sorption is species } \\
\text { dependent }(\mathrm{Se}(\mathrm{VI}) \\
\text { favored in oxidized, } \\
\text { alkaline conditions and }\end{array}$ & $\begin{array}{l}\text { Mobile with oxidized } \\
\text { species (Se(IV), Se(VI) } \\
\text { more mobile than } \\
\text { reduced species (Se(0), } \\
\text { Se(II; Huang and Fujii } \\
\text { 1996) }\end{array}$ & $\begin{array}{l}\text { Mining or drainage/ } \\
\text { irrigation of seleniferous } \\
\text { soils (Goldberg et al. } \\
\text { 2006) }\end{array}$ \\
\hline
\end{tabular}


Table 1 (continued)

\begin{tabular}{|c|c|c|c|c|c|}
\hline Element & $\begin{array}{l}\text { Ionic } \\
\text { Form }\end{array}$ & $\begin{array}{l}\text { Parent materials } \\
\text { with high concentrations } \\
\text { of the element }\end{array}$ & General reactivity in soils & Mobility & Sources of pollution \\
\hline $\mathrm{Zn}$ & $\mathrm{Zn}(\mathrm{II})$ & $\begin{array}{l}\text { Low but relatively similar } \\
\text { content in most geologic } \\
\text { materials, but higher } \\
\text { concentrations when } \\
\text { sulfides present in rock. } \\
\text { Ore deposits of } \mathrm{Zn} \\
\text { sulfide, sphalerite. }\end{array}$ & $\begin{array}{l}\text { in solution; Se(IV), if } \\
\text { present, is strongly } \\
\text { adsorbed by soil). Se(IV) } \\
\text { considered more toxic. } \\
\text { (Fio et al. 1991, } \\
\text { Goldberg et al. 2006) } \\
\text { Specific adsorption by } \\
\text { carbonates, clays, oxides, } \\
\text { and organic matter } \\
\text { (Romkens and Salomons } \\
\text { 1998; Reed and Martens } \\
\text { 1996); may be present as } \\
\text { exchangeable cation } \\
\text { (Reed and Martens 1996); } \\
\text { adsorption involving } \\
\text { exchange sites in acid soil } \\
\text { conditions, chemisorption } \\
\text { with organic ligands in } \\
\text { alkaline conditions } \\
\text { (Kabata-Pendias and } \\
\text { Pendias 2001). }\end{array}$ & $\begin{array}{l}\text { Generally non-mobile due } \\
\text { to adsorption on organic } \\
\text { and mineral surfaces, but } \\
\text { biocycling results in } \\
\text { increasing surface } \\
\text { concentrations (Reed and } \\
\text { Martens 1996, Kabata- } \\
\text { Pendias and Pendias } \\
\text { 2001) }\end{array}$ & $\begin{array}{l}\text { Municipal sludge, waste } \\
\text { from smelting, poultry, } \\
\text { and swine manure (Reed } \\
\text { and Martens 1996) }\end{array}$ \\
\hline
\end{tabular}

soluble complexes bound to clay or organic compounds (Quantin et al. 2002; Sommer et al. 2000). Arsenic, $\mathrm{Se}$, and $\mathrm{Cr}$ are three elements that change oxidation state with changing redox conditions in the soil, affecting their speciation, solubility, mobility, and toxicity. Arsenic has been found to bioaccumulate in wetland plants and organisms in wetlands (Chen et al. 2002). It has low solubility under oxidizing conditions $[\mathrm{As}(\mathrm{V})]$, but is much more mobile under reducing conditions as As(III) (Masscheleyn et al. 1991). The oxidized species, arsenate, is an anion and chemically similar (relative to mineral sorption) to phosphate (Harris 2002). Selenite [Se(IV)] is adsorbed more strongly to mineral surfaces and is more toxic, while selenate $[\mathrm{Se}(\mathrm{VI})]$ is adsorbed weakly and is readily leached from soils (Goldberg et al. 2006). Chromium (III), the reduced cationic species, is less toxic and less mobile relative to the anionic species, $\mathrm{Cr}(\mathrm{VI})$. The decreasing mobility is related to bond strength with soil minerals, complexation with soil organics, and formation of oxide/oxyhydroxides in the soil (Stewart et al. 2003).
Elemental cycling via plant absorption and resultant accumulation in the organic fraction of surface horizons is common for some elements such as $\mathrm{Cu}$ and $\mathrm{Zn}$. Elements such as $\mathrm{Cu}, \mathrm{Zn}, \mathrm{Pb}$, and $\mathrm{Ni}$ do not undergo changes in oxidation state in common soil redox conditions. These elements are indirectly affected by changes in solubility and crystallinity of Fe and Mn oxides that may change with soil redox status. These oxides (as well as organic matter) are important adsorbing or complexing agents. As organically complexed ions or colloidal oxides, movement of these elements $(\mathrm{Cu}, \mathrm{Zn}, \mathrm{Pb}$, and $\mathrm{Ni})$ can also occur via diffusion or preferential flow through soils (Shuman 2005; Kabata-Pendias and Pendias 2001; Senesi and Loffredo 2005). Cadmium has lower affinity for these adsorbants (oxides and organic matter) and is more readily absorbed and translocated through plants (Basta et al. 2005).

Soil $\mathrm{pH}$ is another important factor influencing element or trace element mobility. As $\mathrm{pH}$ decreases, trace elements in exchangeable, complexed, or precipitated forms can be released and subject to mobilization. 
Table 2 Variations in $\mathrm{Ni}, \mathrm{Pb}$, and $\mathrm{Zn}$ in 22 pedons developed from different parent materials sorted by increasing Ni concentration

\begin{tabular}{|c|c|c|c|c|c|c|c|}
\hline $\begin{array}{l}\text { Soil } \\
\text { name }^{\mathrm{a}}\end{array}$ & $\begin{array}{l}\text { Location } \\
\text { (County, State) }\end{array}$ & $\begin{array}{l}\text { Subgroup } \\
\text { Classification }^{\mathrm{b}}\end{array}$ & Parent Material & $\begin{array}{l}\text { No. } \\
\text { Hzns }^{\mathrm{c}}\end{array}$ & $\mathrm{Ni} \mathrm{mg/kg}$ & $\mathrm{Pb} \mathrm{mg/kg}$ & $\mathrm{Zn} \mathrm{mg/kg}$ \\
\hline DryGyp & Clark, NV & Typic Palegypsid & Gypsiferous rock & 6 & $1.7 \pm 1.8$ & $0.3 \pm 2.0$ & $6.4 \pm 9.0$ \\
\hline Valentine & Dundy, NE & Ustic Torripsamment & Eolian sands & 4 & $2.4 \pm 0.1$ & $2.4 \pm 0.3$ & $11.6 \pm 0.7$ \\
\hline Cecil & Oconee, GA & Typic Kanhapludult & $\begin{array}{l}\text { Matamorphic-acidic } \\
\text { material }\end{array}$ & 5 & $6.5 \pm 2.0$ & $20.7 \pm 4.0$ & $26.8+7.7$ \\
\hline Gilpin & Raleigh, WV & Typic Hapludult & $\begin{array}{l}\text { Sandstone/Sitstone/ } \\
\text { Shale }\end{array}$ & 9 & $8.3 \pm 2.6$ & $10.2 \pm 3.1$ & $44.7 \pm 7.9$ \\
\hline Bama & Autauga, AL & Typic Paleudult & $\begin{array}{l}\text { Fluvial or marine } \\
\text { sediments }\end{array}$ & 6 & $15.4 \pm 7.4$ & $11.9 \pm 2.7$ & $27.5 \pm 12.8$ \\
\hline Gilpin & Fayette, WV & Typic Hapludult & Shale & 8 & $16.8 \pm 3.7$ & $12.9 \pm 3.4$ & $51.0 \pm 7.0$ \\
\hline Matewan & Raleigh, WV & Dystric Eutrudept & $\begin{array}{l}\text { Sandstone/siltstone/ } \\
\text { shale }\end{array}$ & 9 & $18.1 \pm 4.8$ & $14.4 \pm 3.9$ & $102.8 \pm 16.3$ \\
\hline Miami & Delaware, IN & Oxyaquic Hapludalf & $\begin{array}{l}\text { Ground Moraine/ } \\
\text { Till Plain }\end{array}$ & 5 & $20.8 \pm 6.1$ & $9.0 \pm 15.1$ & $74.3 \pm 17.7$ \\
\hline Monona & Monona, IA & Typic Hapludoll & Loess & 11 & $29.2 \pm 2.8$ & $13.5 \pm 0.6$ & $84.0 \pm 3.1$ \\
\hline Saum & Yamhill, OR & Ultic Palexeralf & Basalt Colluvium & 6 & $31.2 \pm 3.3$ & $8.7 \pm 1.4$ & $219.7 \pm 24.8$ \\
\hline Manor & Howard, MD & Dystric Eutrudept & Micaceous schist & 8 & $37.4 \pm 112.5$ & $17.7 \pm 24.0$ & $119.0 \pm 105.5$ \\
\hline Goss & Saline, MO & Typic Paleudalf & Cherty Limestone & 3 & $52.2 \pm 32.5$ & $22.8 \pm 11.4$ & $95.9 \pm 38.8$ \\
\hline Pane & Maui, HI & Humic Haplustand & $\begin{array}{l}\text { Volcanic ash over } \\
\text { basalt }\end{array}$ & 6 & $61.6 \pm 23.3$ & $<$ Det. Lim. & $207.5 \pm 20.2$ \\
\hline Jackland & Baltimore City, MD & Vertic Hapludalf & Diorite & 10 & $63.4 \pm 171.8$ & $10.7 \pm 14.5$ & $29.7 \pm 8.2$ \\
\hline Brazilton & Crawford, KS & Alfic Udarent & $\begin{array}{l}\text { Reclaimed Mine } \\
\text { Spoil-Shale }\end{array}$ & 8 & $69.0 \pm 11.0$ & $23.7 \pm 5.2$ & $118.4 \pm 18.7$ \\
\hline Threetrees & Curry, OR & Typic Dystrudept & Schist & 6 & $70.5 \pm 22.3$ & $52.1 \pm 77.8$ & $149.3 \pm 37.3$ \\
\hline Coto & Aguas Buenas, PR & Typic Eutrodox & Limestone & 7 & $71.6 \pm 3.5$ & $21.6 \pm 1.2$ & $84.6 \pm 4.4$ \\
\hline Altamont & Colusa, CA & Chromic Haploxerert & $\begin{array}{l}\text { Graywacke or } \\
\text { mudstone }\end{array}$ & 4 & $77.3 \pm 2.1$ & $6.9 \pm 0.3$ & $164.8 \pm 3.3$ \\
\hline Waimea & Hawaii, HI & Andic Haplustoll & Basalt & 7 & $79.0 \pm 37.7$ & $0.1 \pm 0.0$ & $182.2 \pm 28.8$ \\
\hline Ferncat & Humboldt, CA & Pachic Hapludoll & Mudstone and/or sandstone & 6 & $95.1 \pm 18.8$ & $7.4 \pm 0.8$ & $100.0 \pm 9.0$ \\
\hline Nipe & Aguas Buenas, PR & Anionic Acrudox & Ultrabasic & 3 & $835.9 \pm 117.2$ & $2.8 \pm 0.6$ & $96.8 \pm 11.4$ \\
\hline Serpetano & Curry, OR & Dystric Eutrudept & Serpentinite & 8 & $2423.6 \pm 753.2$ & $5.0 \pm 19.6$ & $207.7 \pm 32.6$ \\
\hline
\end{tabular}

Elemental data represent median value ( \pm median absolute deviation) of horizons within each pedon

$P R$, Puerto Rico

${ }^{a}$ Series name assigned during sampling

${ }^{\mathrm{b}}$ Classification (Soil Taxonomy, 2006) based on lab data and field description

${ }^{\mathrm{c}}$ Number of horizons analyzed per pedon

Seasonal changes in $\mathrm{pH}$ may influence metal solubility especially in wetlands (Gambrell 1994), where associated fluctuations in salinity also influence elemental sorption and mobility.

Correlation of data routinely obtained during soil survey activities (e.g., Fe oxides, carbonates, salinity, particle size, organic matter) can be useful predictors of the concentration and reactivity of trace elements at the landscape scale (Burt et al. 2003b; Ma et al. 1997; Pardue et al. 1992; Mermut et al. 1996). This relationship provides evidence of the importance of common soil components influencing pedogenic distribution and supports the examination of geochemistry of soils within the context of a soil survey.

Anthropogenic additions

Anthropogenic additions are an important source of trace elements in certain localized settings (Mermut et al. 1996; Burt et al. 2003a) and occur from a wide variety of sources such as mining, smelting, industrial, transportation, military, and agricultural activities. An 
element with a concentration above an established background level is considered a contaminant, yet this level does not necessarily imply the element is causing harm (pollutant) or is particularly hazardous to humans or biota (toxic; Pierzynski et al. 2000; Kabata-Pendias and Pendias 2001). Contamination is often attributable to point sources, though distribution of pollutants may encompass a large geographic area. If a source of pollution is known, then extent of aerial distribution is a key to understanding degrees of contamination (Liao et al. 2005). Generally, the concentration of metals will decrease with distance from the source (Pietz et al. 1978), though in contaminated areas, short range variability in concentration can be erratic due to wind and water redistribution (Markus and McBratney 1996; Burt et al. 2003a).

There is speculation that purely background levels (pristine soils free of human-induced pollution) do not exist in many parts of the US and world due to changing landuse history and long range atmospheric deposition of pollutants (Chen et al. 1999; Steinnes et al. 2005). A key factor of concern for trace elements is the long residence time and their general insolubility (high solid to solution partition coefficient) once adsorbed by soil components (Markus and McBratney 1996; Basta et al. 2005). A second aspect of concern is food chain bioaccumulation with the subsequent risk to human health. Two well-documented examples of bioaccumulation are tuna contaminated with high concentrations of mercury (Waldman 2005; Burger and Gochfeld 2004) and the occurrence of Itai-itai disease in Japan from the consumption of Cd contaminated rice (Nogawa et al. 1983; Förstner 1995).

The goal of remediation specialists and land use planners is to recognize and separate elemental concentrations that reflect native pools (parent material and pedogenic sources) from the anthropogenic pool within a given soil. The best measure of possible anthropogenic additions is through comparison of the study area to analogous soils with trace element levels attributable only to background sources. These "similar" soils used to derive suitable background values should be developed from soils with comparable parent material and genetic history (age, landscape position, climatic regime, etc.) to the site in question. Determination of similar sites can be facilitated by applying soil survey information. A soil survey segregates landscapes into similar soil components based on soil forming factors and uses Soil Taxonomy (Soil
Survey Staff 1999) as a classification tool to label (or "identify") soils with similar properties.

Histograms are useful to compare data from a particular site to the range of trace element concentrations of a larger group of soils. This technique is useful due to the diverse and wide range in concentration of metals in soils and allows a soil to be placed in a relative context. Figure 2 illustrates that a group of elements $(\mathrm{Cu}, \mathrm{Ni}, \mathrm{Zn}, \mathrm{Co}$, and $\mathrm{Pb})$ have median values in surface horizons of nonanthropogenically influenced soils that range from 9.1 to $15.8 \mathrm{mg} / \mathrm{kg}$, with a 1000 fold range in concentration. Chromium is similar (median $=23.9 \mathrm{mg} / \mathrm{kg}$ ), though its natural range in this dataset is 10,000 fold ( 0.41 to $6029 \mathrm{mg} / \mathrm{kg}$ ). Cadmium and $\mathrm{Hg}$ have lower natural concentrations ranges in soils than the other elements. In general, these values are very similar to median values and ranges reported by Förstner (1995) and Shacklette and Boerngen (1984).

Histograms for anthropogenically influenced soils (Fig. 2) generally reflect higher median values and wider ranges for specific elements. For example, median $\mathrm{Cu}$ values for anthropogenically influenced soils are 35.1 versus $15.2 \mathrm{mg} / \mathrm{kg}$ in non-contaminated soils, with a range up to $1837 \mathrm{mg} / \mathrm{kg}$ compared to $377 \mathrm{mg} / \mathrm{kg}$, respectively. This disparity of values between anthropogenically influenced and native soils is especially striking for $\mathrm{Pb}$, with a median value of 36.5 versus $9.9 \mathrm{mg} / \mathrm{kg}$, respectively.

Cumulative frequency diagrams are very useful to examine these data to gain additional insight into population distributions. About $90 \%$ of the samples for $\mathrm{Cu}$ within the non-anthropogenic population are $<70 \mathrm{mg} / \mathrm{kg}$ [Fig. 3(Cu)], whereas the value increases up to $300 \mathrm{mg} / \mathrm{kg}$ for anthropogenically influenced soils. An opposite trend is apparent for Co $(90 \%$ of non-anthropogenic samples are $<60$ and $<20 \mathrm{mg} / \mathrm{kg}$ for anthropogenically influenced samples; Fig. 3(Co)] illustrating that every element may not be elevated in every trace element or that native concentrations of certain elements are naturally high for selected soils. Other elements that exhibit similar cumulative frequency diagrams relationships between the anthropogenically influenced and non-contaminated datasets (as Co) are $\mathrm{Mn}$ and $\mathrm{Ni}$. The trend for $\mathrm{Ni}$ is likely related to inclusion of pedons with elevated natural concentrations derived from serpentinite rocks. Thus, use of any geochemical dataset (individual site or regional comparisons) requires knowledge of pedons 

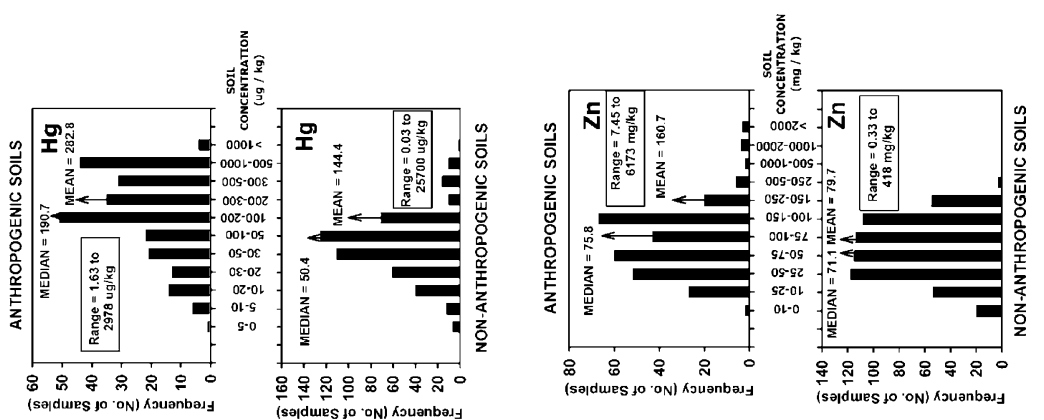

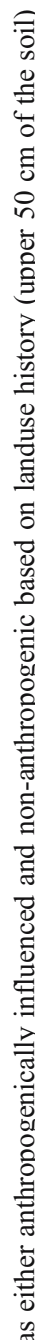
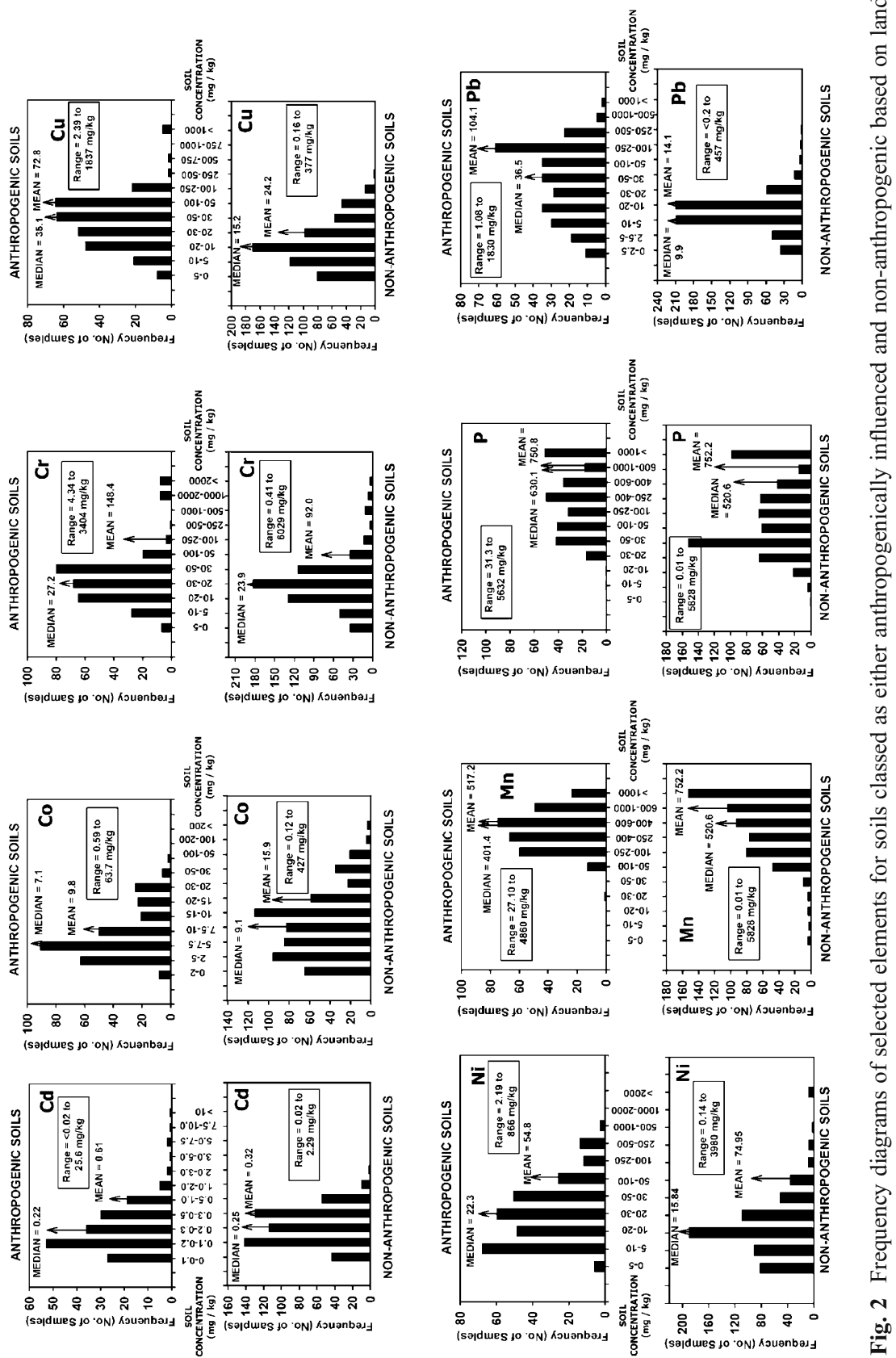
sampled as well as characteristics of the soils in the area of concern.

An alternative approach for evaluating possible anthropogenic additions at a site is to examine the concentration of an element in a surface compared to subsoil horizons. This evaluation recognizes that an elevated surface concentration may be an indicator of metal deposition (Esser et al. 1991; Romkens and Salomons 1998; Steinnes et al. 2005). The approach will be problematic in cases where changes in depth functions of elemental concentrations result from multiple lithologies within the soil profile or pedogenic alterations such as soil-plant elemental cycling related to organic matter accumulation. Also, understanding landscape hydrology in an area are essential to proper site selection and interpreting data. Groundwater flow paths through the landscape (Richardson et al. 2001) impact elemental redistribution and may concentrate certain elements at discharge sites (Sherman 1952; Fio et al. 1991; Lee et al. 2001).

\section{Bioavailability}

The bioavailability and toxicity of an element are very difficult to predict and there is no agreement on a single procedure to document such characteristics for an element. The total concentration of an element in soil is generally acknowledged as the best approach whereby to understand the degree to which a soil may be contaminated or pose a health risk to humans. This approach requires comparing concentrations of an element at a site in question to similar non-contaminated soils and will vary by soil type. Careful selection of comparable sites is critical to evaluate native concentrations of metals and to account for metal enriched soils that are natural. This need to document possible contamination has resulted in a number of statewide (Ma et al. 1997; Franklin et al. 2003; Ciolkosz et al. 1993a,b, 1998; Bradford et al. 1996; Pettry and Switzer 1993; Ammons et al. 1997; Chen et al. 1999) and national studies (Shacklette and Boerngen 1984; Holmgren et al. 1993) of trace element concentrations in soils in the US. One aspect of importance is that some of these studies may be based more on easily obtained "grab" samples than by careful site selection by landscape evaluation.

There is international recognition of the importance of understanding the geochemistry of soils. Both Canada (Haluschak et al. 1998) and Japan (Takeda et al. 2004) have completed studies relating geochemistry to soil types. The international geoscience community for many years focused on geochemistry of stream sediments related to mineral resource exploration. Recently, they have shifted emphasis to the understanding the geochemical composition of the earth's surface in an effort of achieving sustainable worldwide development (Darnley et al. 1995; Plant et al. 2000). Darnley et al. (1995) discusses the need for international standardization of sampling and the development of analytical schemes for both continental and sub-continental (regional) geochemical studies. An objective of these studies is to identify regional scale processes influencing abundance (deficiencies and excesses), and the mobility and bioavailability of elements. Examples of completed studies include China (Xie and Yin 1993), the Baltic Soil Survey
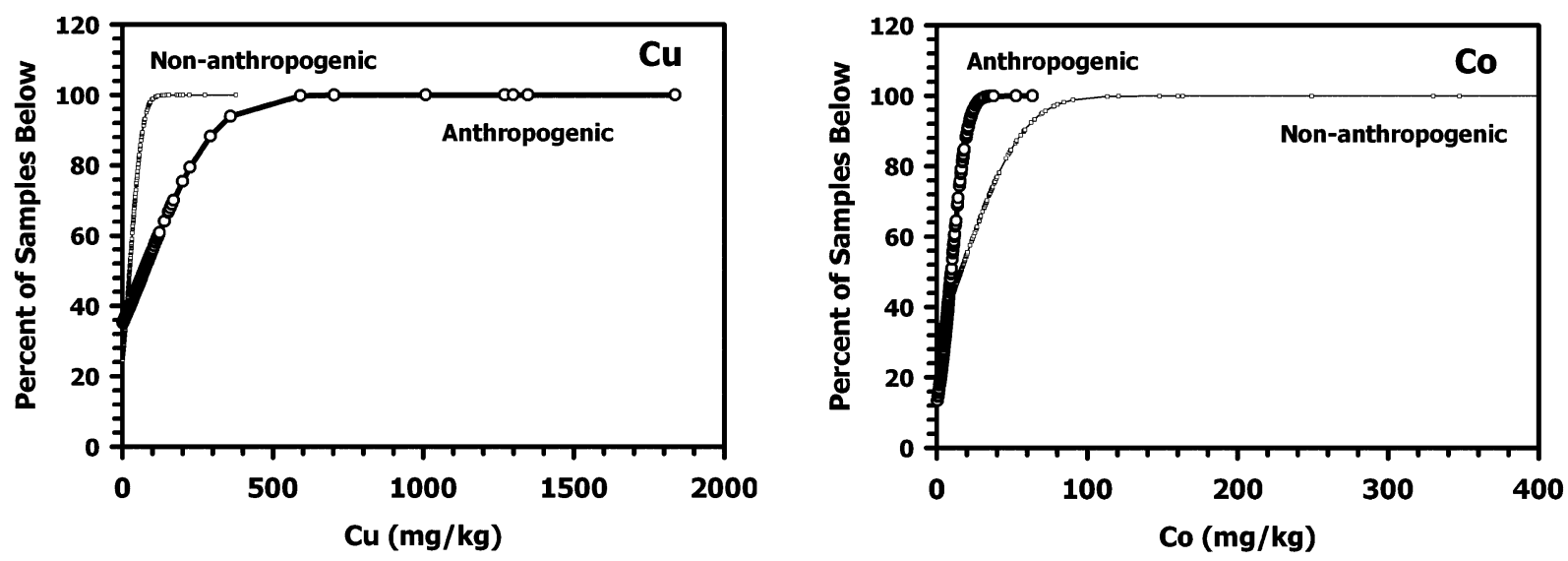

Fig. 3 Cumulative frequency diagrams for $\mathrm{Cu}$ and $\mathrm{Co}$. Plots are for non-anthropogenic and anthropogenic-influenced datasets 
(Reimann et al. 2000), which includes geochemistry of 10 countries from northern Europe, and the FOREGS (Forum of European Geological Surveys) project spanning 26 European countries (Salminen et al. 2005). A low density geochemical survey for mineral exploration was performed in Canada and included both soils and till (Garrett and Thorleifson 1991; Garrett 1994).

Bioavailability depends upon the reactivity or behavior of an element in soils. This is an extremely complex phenomenon related to both the chemistry of the soil $(\mathrm{pH}$, redox potential, cation exchange capacity, mineral and organic composition) and physiochemical form of the element (Singh 1997; Table 1). The retention of each element depends on an intricate equilibrium between soluble and complexed forms, and reaction with soil particles (Renella et al. 2004). The free metal ion in solution is the more biologically active species in soils compared to complexed, colloidal, or sorbed forms (Sauve and Parker 2005). A key question concerning concentrations of trace elements is often not the total concentration, but the degree of risks or hazards from specific species of a particular element. To better understand the forms of an element in soils, researchers examine the speciation through direct analytical measurements, often in association with computer modeling, or by fractionation (D'Amore et al. 2005). Fractionation or "geochemical partitioning" is another technique involving examination of the relative amounts of an element sequentially extracted by a series of chemical solutions of increasing "strength" (e.g., water $\rightarrow$ neutral salts $\rightarrow$ chelating agents $\rightarrow$ organic acids) that target specific chemical forms, e.g., soluble, exchangeable, or adsorbed fractions (Tessier et al. 1979; Burt et al. 2003a).

Pathways of elements from soils to humans (soil, plant, animal, human) and the relative mobility or toxicity of an element in each pathway segment should be determined to evaluate probable risk (Chaney et al. 2000; Basta et al. 2005). The mobility of an element within the food chain ultimately affects the likelihood of an adverse affect on humans. A major health concern is the risk of excess trace elements entering humans via consumption of plants or animals that have absorbed high concentrations of an element. A second concern is the risk from direct ingestion of soil by humans. The fraction of the soil trace element that is available for sorption is "bio- available". Plant absorption of soil trace elements is of specific concern and many studies test extracting solutions that correlate to plant concentrations. These extractants are designed to remove a portion of the element from the soil that is absorbed by plants (Houba et al. 1996; McBride et al. 2003; Darmody et al. 2004) and are similar to soil fertility tests. Yet, no single extractant common to all elements or plant species for a bioavailability-based measurement exists. Bioavailability of an element within the human stomach is estimated based on the solubility and release of the metal ion from soils using specific chemical conditions that mimic the human digestive system (Yang et al. 2002; Stewart et al. 2003; Fendorf et al. 2004).

The differing degrees of elemental absorption, as well as tolerance exhibited by plant species are well known (Kukier and Chaney 2001). This degree of absorption, termed phytoextraction, is being explored as a means of soil remediation. The process is viewed as efficient and environmentally sound (Chen et al. 2004) and is being performed by plants that are "hyperaccumulators", capable of absorbing large amounts of trace elements $(>1,000 \mathrm{mg} / \mathrm{kg}$ in above ground biomass) from contaminated soils (Lombi et al. 2001; Cong and Ma 2002).

\section{Geochemistry in soil survey}

Organization for sample collection

Soil surveys are ideally suited for developing a sampling strategy for soil geochemical studies. The grouping (mapping and classification of soils) provides the basis for the systematic study of soils in their natural settings; i.e. the soil landscape. Soil properties exhibit systematic variability based on factors of soil formation (Upchurch and Edmonds 1991). The development of landscape models, refined using laboratory, site, and morphological data, allows identification of the dominant soil component on each landscape unit. Soil maps developed from these data and models provide a basis for understanding soil geographic variability at local, regional, national, and global levels (Soil Survey Staff 1999). Knowledge of the spatial variation within and among soils provides a basic and powerful structure that is useful in designing soil geochemical studies that yield the 
Table 3 Elemental data and summary statistics from A and BC horizons of pedons sampled as Highsplint in West Virginia

\begin{tabular}{|c|c|c|c|c|c|c|c|c|c|c|c|c|c|}
\hline & As & $\mathrm{Ba}$ & $\mathrm{Be}$ & $\mathrm{Cd}$ & $\mathrm{Co}$ & $\begin{array}{l}\mathrm{Cr} \\
\mathrm{mg} /\end{array}$ & $\mathrm{Cu}$ & $\mathrm{Mn}$ & $\mathrm{Ni}$ & $\mathrm{Pb}$ & $\mathrm{Sr}$ & $\mathrm{Zn}$ & $\begin{array}{l}\mathrm{Hg} \\
\mu \mathrm{g} / \mathrm{kg}\end{array}$ \\
\hline \multirow[t]{8}{*}{ A horizon } & 10.37 & 330.75 & 1.16 & 0.35 & 14.64 & 20.94 & 15.59 & 1244.44 & 14.86 & 17.25 & 34.21 & 77.41 & 100 \\
\hline & 17.48 & 78.10 & 0.78 & 0.13 & 5.67 & 14.56 & 5.32 & 88.04 & 8.10 & 15.53 & 13.03 & 32.85 & 49 \\
\hline & 14.14 & 318.32 & 1.71 & 0.36 & 15.25 & 21.49 & 17.40 & 895.82 & 25.10 & 22.15 & 20.63 & 117.40 & 59 \\
\hline & 18.50 & 255.56 & 1.51 & 0.42 & 18.30 & 29.55 & 19.92 & 1604.20 & 28.85 & 27.63 & 17.68 & 118.25 & 74 \\
\hline & 7.54 & 81.18 & 0.68 & 0.18 & 8.17 & 17.38 & 9.09 & 159.94 & 11.07 & 13.93 & 4.68 & 52.28 & 36 \\
\hline & 11.67 & 409.98 & 2.06 & 0.44 & 17.15 & 27.64 & 18.35 & 1546.63 & 29.24 & 16.00 & 22.67 & 122.69 & 58 \\
\hline & 8.76 & 162.99 & 1.06 & 0.22 & 9.70 & 25.38 & 9.42 & 904.98 & 14.64 & 28.12 & 12.84 & 65.41 & 74 \\
\hline & 7.56 & 67.52 & 0.32 & 0.16 & 3.75 & 21.44 & 8.25 & 108.04 & 8.86 & 20.95 & 8.35 & 40.42 & 74 \\
\hline median & 11.02 & 209.28 & 1.12 & 0.29 & 12.17 & 21.47 & 12.51 & 900.40 & 14.75 & 19.48 & 15.36 & 71.41 & 67 \\
\hline mean & 12.00 & 213.05 & 1.16 & 0.28 & 11.58 & 22.30 & 12.92 & 819.01 & 17.59 & 20.45 & 16.76 & 78.34 & 66 \\
\hline $\mathrm{cv}^{\mathrm{a}}$ & 0.36 & 0.63 & 0.50 & 0.44 & 0.47 & 0.23 & 0.43 & 0.77 & 0.50 & 0.26 & 0.55 & 0.47 & 0.3 \\
\hline \multirow[t]{8}{*}{ BC Horizon } & 14.24 & 148.85 & 1.12 & 0.17 & 6.52 & 27.35 & 13.6 & 200.93 & 17.02 & 13.17 & 22.08 & 61.03 & 47 \\
\hline & 11.03 & 81.55 & 1.34 & 0.11 & 8.88 & 18.31 & 10.42 & 162.64 & 17.49 & 8.79 & 16.63 & 60.10 & 33 \\
\hline & 12.78 & 141.25 & 1.29 & 0.18 & 11.49 & 18.53 & 15.53 & 403.84 & 20.65 & 11.57 & 5.27 & 89.88 & 22 \\
\hline & 15.75 & 119.35 & 1.29 & 0.15 & 9.75 & 23.65 & 18.86 & 452.13 & 23.03 & 11.86 & 10.30 & 83.85 & 53 \\
\hline & 10.35 & 113.43 & 0.95 & 0.16 & 7.65 & 22.34 & 12.77 & 208.19 & 18.23 & 10.64 & 8.15 & 72.68 & 24 \\
\hline & 11.97 & 118.11 & 1.03 & 0.23 & 14.12 & 23.72 & 19.77 & 493.65 & 22.54 & 13.62 & 7.43 & 100.52 & 39 \\
\hline & - & 85.97 & 0.86 & 0.13 & 8.71 & 25.76 & 11.83 & 227.10 & 18.65 & 13.23 & 9.80 & 44.88 & 49 \\
\hline & 12.34 & 357.17 & 1.34 & 0.10 & 10.92 & 30.75 & 32.22 & 609.70 & 18.61 & 19.39 & 36.10 & 92.28 & 106 \\
\hline median & 12.34 & 118.73 & 1.21 & 0.16 & 9.32 & 23.69 & 14.30 & 315.47 & 18.63 & 12.52 & 10.05 & 78.27 & 43 \\
\hline mean & 12.64 & 145.71 & 1.15 & 0.15 & 9.76 & 23.81 & 16.81 & 344.77 & 19.53 & 12.78 & 14.47 & 75.65 & 47 \\
\hline $\mathrm{CV}$ & 0.15 & 0.61 & 0.16 & 0.27 & 0.25 & 0.18 & 0.42 & 0.48 & 0.12 & 0.24 & 0.71 & 0.25 & 0.6 \\
\hline
\end{tabular}

${ }^{\mathrm{a}} \mathrm{CV}$, coefficient of variation for mean

maximum amount of information for the time and effort invested in sampling and laboratory analysis. In their study of the derivation of geochemical background values, Reimann et al. (2005) concluded that factors related to soil forming processes such as similarity of soil parent material (geology), climate, and vegetative cover are critical criteria in designing geochemical studies.

The physical entity of the dominant, representative component of a soil mapping units is termed the "pedon". The selected pedon is named for a soil series, the lowest category in Soil Taxonomy. As a taxonomic class, a series is a group of soils that have horizons similar in arrangement and in differentiating characteristics (Soil Survey Division Staff 1993). The common differentiating characteristics are quantifiable; though the underlying thread has a process or genetic basis. Series serve as a major vehicle to transfer soil information and research knowledge from one soil area to another (SSSA 1997) and therefore can be a powerful tool for understanding geochemical variation within and among soil series. More than 20,000 series have been recognized in the United States (Soil Survey Staff 1999). The NCSS has designated a subset of important series as "benchmarks soils". Benchmark soils have large extent, key position in the soil taxonomic system, or special significance for landuse (Soil Survey Staff 2006). There are currently 1,255 benchmark series (USDA-NRCS 2005a). Benchmark soils are regarded as the most critical series to characterize and emphasis has been placed on collecting data on representative pedons of these series.

These selected soils routinely undergo characterization of chemical, physical, and mineralogical properties on all major horizons (Soil Survey Staff 1999) and it is advantageous to obtain geochemical analyses on these same representative pedons. Site and morphological properties of representative pedons are documented. Detailed observations on geologic origins and information related to mineralogy should be recorded in pedon descriptions of observed and sampled sites for optimum use of these 
Fig. 4 Box and whisker plots for selected elements from $\mathrm{A}$ and $\mathrm{BC}$ horizons of pedons sampled as the Highsplint series in West Virginia. The midpoint of the box is the median of the data, while the left and right ends of the box illustrate the median of the values below (lower quartile) and above (upper quartile) the median, respectively. Whiskers on either end of the box represent lower and upper extremes of data
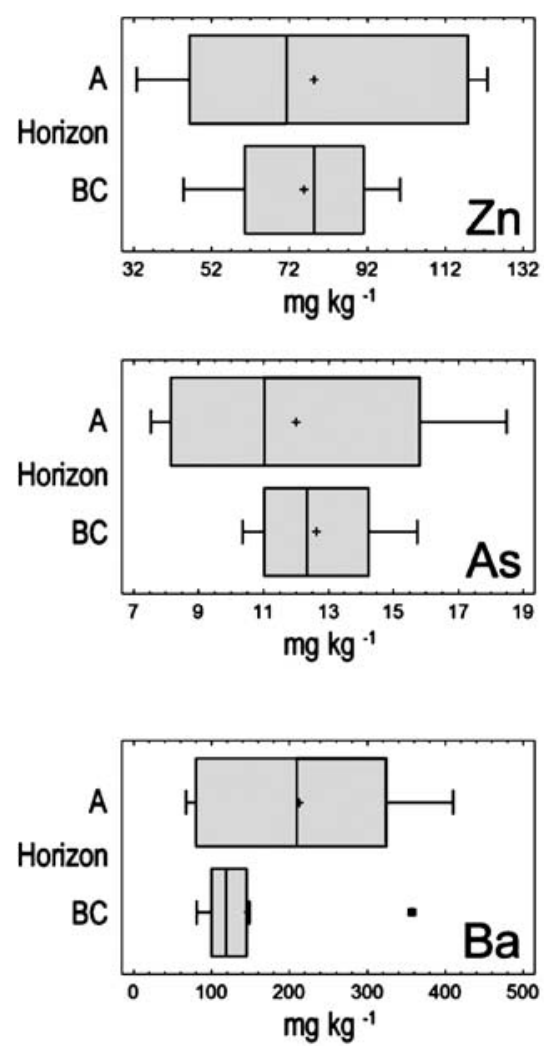
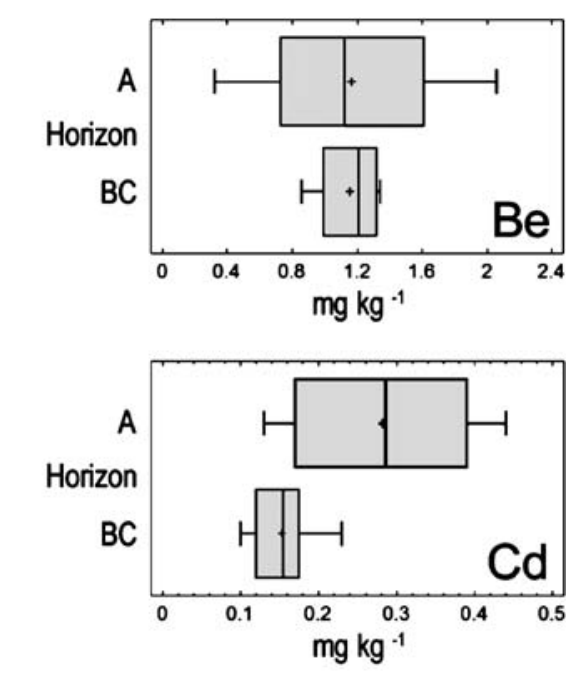

Environ Monit Assess (2008) 139:151-171

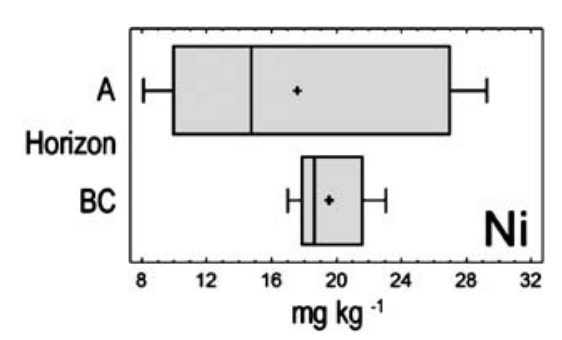

locations for geochemical evaluation and correlation. This analytical approach associates geochemistry data, analyzed to $2 \mathrm{~m}$ deep (or lithic contact), with landscape, soil morphological data, and other physical and chemical properties.

Trace element variation within series

Background values established for geochemical soil interpretations should document the natural distribution of an element and are generally not a single value, but a range or another statistically derived value, and must account for spatial aspect of the geochemical data (Chen et al. 1999; Reimann et al. 2005). Soil variability has been extensively studied, approached from both a theoretical, modeling basis (Heuvelink and Webster 2001; McBratney et al. 2000) and by evaluation of variability for specific soil properties based on scale of mapping (Leenhardt et al. 1994). Geochemical variability by soil order has been evaluated (Ma et al. 1997; Chen et al. 2002; Burt et al. 2003b) and geochemical variability between different series has been documented in statewide studies. Yet, utility of background values established for representative pedons should examine variability among pedons of a single series as well. Evaluation of variability of these data within a series will require a much larger dataset and range of data for a specific element will likely vary based on uniformity of regolith on which a series is mapped.

Geochemical data on selected West Virginia soils has been produced on replicate pedons to evaluate this variability. Table 3 illustrates data from the surface (A horizon) and subsoil (BC horizon) from eight pedons of mapping units of the Highsplint Series. The Highsplint (loamy-skeletal, mixed, active, mesic Typic Dystrudepts) consists of deep and very deep soils in mountains and hills developed from stony, loamy colluvium weathered from sandstone, siltstone, and shale. These pedons generally have uniform clay contents and decreasing organic $\mathrm{C}$ and $\mathrm{NH}_{4}$ acetateextractable $\mathrm{Ca}+\mathrm{Mg}$ with depth (data not shown). The geochemistry data illustrate the range of variability of elemental composition among these pedons (Table 3). For example, $\mathrm{Cu}$ ranges from 5.3 to $19.9 \mathrm{mg} / \mathrm{kg}$ in the surface horizons. The range in 
elemental data for surface horizons is generally wider than for the lower (BC) horizons (Fig. 4). This trend is also supported by the lower coefficient of variation for elements in the subsoil compared to surface horizons (Table 3). These lower range in data for surface horizons indicates that even though environmental concerns are often focused on topsoils, more meaningful relationships derived from soil survey data may come from subsoils. Lower horizons are often more geochemically controlled by parent material relationships as opposed to depositionally and biocycliccontrolled amounts in surface horizons.

Geochemical applications within soil survey

Geochemistry data can be used to define ranges of soil properties for soil series or mapping units, including taxonomic placement (Burt et al. 2001). It has been useful in characterizing pedon and landscape processes such as direction or extent of weathering and determining the nature or origins of parent materials (Jersak et al. 1997; Wilcke and Amelung 1996; Muhs et al. 2001).

Soil quality/soil health decisions regarding land use and possible reclamation or restoration often require geochemistry and other related soil characterization data. An early application related to health was the study of molybdenum (Mo) toxicity in cattle due to specific forage species and soil properties in Nevada (Kubota et al. 1961). This study documented the influence of parent material, soil moisture status, and surface horizon thickness on the content and supplying capacity of Mo to legume and grasslegume pastures. A current example is the involvement of USDA-NRCS in stream restoration efforts in several areas of the US (USDA-NRCS 2005b). One ongoing project is the Willow Creek Reclamation Project near the town of Creede, Colorado. Acid mine drainage has resulted in elevated $\mathrm{Zn}, \mathrm{Cd}$, and $\mathrm{Pb}$ in the creek and riparian area and has altered Willow Creek to the extent that populations of fish and other aquatic species can not be maintained (Taylor et al. 2001). The objectives of the project are to reclaim damaged riparian areas along the stream created by past mining activities and improve the economic viability of the area. This is being accomplished in part with a designed sampling scheme to evaluate trace element concentrations in both soil and water.
The update of soil surveys in West Virginia is emphasizing improved characterization of major soils. Central to this effort has been the determination of amounts and distributions of important forest nutrients and trace elements. A sampling design was initiated to provide soil survey information to relate major differences in forest site productivity to geologic composition as quantified by elemental data. These elemental data assist in correlation decisions to add and/or differentiate series in the state and make it possible to provide trace element quantity and distribution data to soil survey users under "native" conditions. Soil surveys in West Virginia are expected to have an expanded utility that will be valuable for forest, agriculture, and waste application management.

Selected pedons sampled as part of soil survey mapping as well as additional sites in North Dakota have been analyzed for trace elements. Interest in trace element distribution was initially stimulated by $\mathrm{Cd}$, an element of concern in the northern tier of states due to its accumulation in durum wheat, confectionary sunflowers, and flax (Li et al. 1997). Production of durum wheat is concentrated in the northern US and Canada and this crop is a major export for use in pasta manufacturing. Unfortunately, concentrations of $\mathrm{Cd}$ in the grain can exceed acceptable limits (House et al. 2003). It is believed that elevated $\mathrm{Cd}$ in this area is related to natural concentrations in till soils and may also be influenced by the use of phosphatic fertilizers. Research has shown that uptake of $\mathrm{Cd}$ from soil by durum wheat is related to soil properties, including salinity (especially chloride; Norvell et al. 2000), and can be spatially related to soils with restricted drainage characteristics (Wu et al. 2002).

Mapping of soils in river basins and other areas of the western US that have elevated Se content is a critical aspect of properly managing this element in aquatic systems. Selenium is an essential element found in food and water, and commercially used in vitamins and some shampoos. It is also known to be carcinogenic if ingested in high concentrations. The element naturally occurs in elevated concentrations in Upper Cretaceous and Tertiary-aged marine sedimentary deposits found in Colorado, California, Utah, Arizona, Nevada, North Dakota, South Dakota, Nebraska, and New Mexico (e.g., Mancos and Pierre Shales). Hazards of Se to waterfowl in the Kesterson Basin in the western San Joaquin Basin, California 
became apparent in the 1980 s where this mobile element was concentrated in irrigation evaporationpond waters (Deverel et al. 1984). The state of Colorado has recognized the potential toxic effects to fish and wildlife. Rivers and lakes in affected areas have Se concentrations commonly exceeding EPA limits $\left(5 \mu \mathrm{g}^{-1}\right)$. A public and multi-agency governmental taskforce (including USDA-NRCS) was formed in the Gunnison Basin of Colorado to assess the problem of $\mathrm{Se}$ from irrigated soils along the Uncompahgre and Gunnison River Basins of the upper Colorado River (http://www.seleniumtaskforce. org/indexold.html).

Baseline elemental data on both recently sampled and archival Nevada soils have been produced to address requests related to soil geochemistry in both rural and urban areas. Mercury contamination exists in some western Nevada soils due to gold milling and smelting of ores dating back to the nineteenth century mining of the Comstock Lode near Virginia City. Contamination of soils by methyl mercury along the Carson River and tributaries to the Truckee River has impacts on stream restoration, constructed wetland projects, and health of fisheries in Lahontan Reservoir and Pyramid Lake (Gustin et al. 1994; Bonzongo et al. 2006). Scientists have also requested soil geochemical data related to $\mathrm{W}$ for investigating a childhood leukemia cluster in Fallon, Nevada. Geochemical data were useful in northwestern Nevada due to concerns of downwind deposition of metal-bearing dust from long-term, open-air destruction of munitions and rocket engines at the Sierra Army Depot near Herlong, California (Burt et al. 2005). Survey level data such as these can be used to evaluate the need for more indepth studies if actions related to soil remediation appear necessary.

Urbanization is placing a greater demand on land in and around cities, and geochemistry of soils in these areas can mirror the shifting patterns of landuse. Natural geographic patterns of soils on landscapes are altered via disturbance, often with the addition of organic or inorganic pollutants. The moniker of "anthropogenic" takes on a much broader meaning for urban soils as human influence is one of the dominant soil-forming characteristics (Evans et al. 2000; Langley-Turnbaugh et al. 2005). Knowledge of geochemistry is regarded as one of the most important issues facing urban land use, and trace element distribution has been an important facet of understanding the urban environment (Chirenje et al. 2003; Murray et al. 2004; Cattle et al. 2002). Howard Mielke has been a pioneer in the effect on public health of elemental contamination of urban areas of both Baltimore (Mielke et al. 1983) and New Orleans (Mielke et al. 1999, 2000; Mielke 2005). He has conducted extensive sampling and trace element analyses for soils in these cities and established direct links of soil concentration to exposure and health affects. Langley-Turnbaugh et al. (2005) used geochemical data to illustrate the complex horizontal and vertical spatial variability that exists in urban soils disturbed from industrial use in the late $1800 \mathrm{~s}$ in Portland, Maine. These authors also found correlations of trace elements with other soil properties, thus anticipating use of these ancillary data (e.g., Fe, clay, $\mathrm{pH}$ ) to help further the evaluation of urban soils in the city. Urbanization is altering the landuse of soils formerly used as orchards in northern Virginia and Maryland. Long term use of insecticides such as lead arsenate has fostered the accumulation of $\mathrm{Pb}$ and $\mathrm{As}$ (Codling and Ritchie 2005). Data are needed on both contaminated orchard soils as well as uncontaminated (baseline) soils to evaluate the extent and potential hazard for future landuse applications.

Soil surveys can document soil-related problems or characteristics in general terms that exist in urban areas by conducting case studies as part of the soil survey. Urban areas have unique distribution of soils and demand different evaluation techniques than conventional soil surveys in rural areas. These soil surveys can also provide guidance or interpretations regarding landuse for playgrounds, gardens, or residential areas where residents are in contact with the soil. Chemical problems of soils are often difficult to recognize in the course of a normal soil survey, but detailed investigations are warranted when problems are suspected (Evans et al. 2000).

\section{Outlook}

There is an ever increasing need to define properties of soils for use and management as well as evaluate the impacts of landuse. Human activities alter the properties of soils and we are becoming increasingly aware of the importance of defining this resource relative to sustaining its use. Measuring the influence 
of humans on soils has been the subject of new "directions" in soil science, whether termed soil quality, use-dependency, soil health, or dynamic change. Tugel et al. (2005) emphasize the mandated importance of soil surveys to address questions of environmental quality and sustainability. Elemental analysis is one of the principal tools we can use to quantify the changing properties of soils from urban, industrial, recreational, forest, and agricultural use. Geochemistry also has additional applications within the soil survey program in relation to soil genesis, taxonomic classification, and reclamation. The development of these data will enhance the utility of soil surveys and will broaden the types of future clientele.

Soil survey has a long history of utilizing geochemical information to elucidate soil processes and define soil components. Elemental analysis, whether it is from an exchange or adsorption/desorption reaction, selective dissolution, or total analysis, is the "bread and butter" of laboratory data that is provided for understanding the properties of soils. For soil survey, these data are produced on benchmark pedons, selected by field scientists to represent the major soil components in a landscape unit. Detailed observations on geologic origins and mineralogy need to be recorded in pedon descriptions of observed and sampled sites for optimum use of these locations for geochemical analysis. This information is required due to the important relationship of trace element content to soil parent materials.

Analysis of these benchmark pedons by genetic horizons throughout the depth of the soil greatly increases the utility of the data compared to samples taken on surface horizons only. Also, geochemistry data produced by soil survey is part of a comprehensive dataset that links site specific data to landform, landscape, Major Land Resource Area (MLRA), state, and national interpretations. Future studies of elemental distribution in selected watersheds and development of landscape models will aid in our understanding of geochemical distribution, but will also function as a methodology for developing models for MLRA updates in soil survey.

The optimal role of scientists in the NCSS Program relative to geochemistry is to provide an understanding of trace element ranges for different soils, parent materials, and regions, and assist in interpreting these data based on soil geography, pedogenic processes, and basic characterization data. Soil scientists can help users of our soil information understand landscape distribution of soils, processes in soils that lead to elemental segregation, and the degree of variability in soil properties that occur in a landscape. In this way, users of soil survey information (including geochemists) can make educated decisions regarding potential problems that may exist in specific areas. In addition, a soil scientist has an understanding of chemical and physical properties and processes in soils and this knowledge could be used to inform the public relative to minimizing potential hazards of landuse. Common techniques to decrease trace element bioavailability and potential hazard are burial, adjusting soil $\mathrm{pH}$, or adding organic materials, phosphates, or Fe oxides to sequester or immobilize these elements (Chaney et al. 2000; Kukier and Chaney 2001; Illera et al. 2004). Other solutions are in situ capping, or excavation and removal. Soil scientists can communicate these types of methodologies to the public relative to landuse in potentially contaminated areas even without site specific data regarding levels of targeted elements and/or knowledge of bioavailability. The assistance soil scientists provide to the public on issues related to soil geochemistry can be a key to keeping soil survey relevant to user needs in the future.

\section{References}

Alban, L. A., \& Kubota, J. (1960). A study of extractable soil cobalt in soils of the southeastern United States. Soil Science Society of America Proceedings, 24, 183-185.

Amacher, M. C. (1996). Nickel, cadmium, and lead. In D. L. Sparks, et al. (Eds.), Methods of soil analysis. Part 3: Chemical Methods (pp. 739-768). Soil Science Society of America Book Series No. 5. Madison, WI: Soil Science Society of America.

Ammons, J. T., Lewis, R. J., Branson, J. L., Essington, M. E., Gallagher, A. O., \& Livingston, R. L. (1997). Total elemental analysis for selected soil profiles in Tennessee. Bulletin 693. Knoxville, TN: The University of Tennessee Agriculture Experimental Station.

Bartlett, R. J., \& James, B. R. (1996). Chromium. In D. L. Sparks, et al. (Eds.), Methods of soil analysis. Part 3: Chemical Methods (pp. 683-701). Soil Sci. Soc. Amer. Book Series No. 5. Madison, WI: Soil Science Society of America.

Basta, N. T., Ryan, J. A., \& Chaney, R. L. (2005). Trace element chemistry in residual-treated soil: Key concepts and metal bioavailability. Journal of Environmental Quality, 34, 49-63.

Bonzongo, J. C., Nemer, B. W., \& Lyons, W. B. (2006). Hydrologic controls on water chemistry and mercury 
biotransformation in a closed river system: The Carson River, Nevada. Applied Geochemistry, 21, 1999-2009.

Bradford, G. R., Chang, A. C., Page, A. L., Bakhtar, D., Frampton, J. A., \& Wright, H. (1996). Background concentrations of trace and major elements in California soils. Kearney Foundation Special Report. Univ. Calif., Davis. Retrieved April 23, 2007: http:/www.envisci.ucr. edu/downloads/chang/kearney/kearneytext.html.

Brown, I. C., \& Byers, H. G. (1935). The chemical and physical properties of dry-land soils and their colloids. Tech. Bull. No. 502. Washington, DC: US Department of Agriculture.

Burger, J., \& Gochfeld, M. (2004). Mercury in canned tuna: White versus light and temporal variations. Environmental Research, 96, 239-249.

Burt, R. (Ed.) (2004). Soil survey laboratory methods manual. SSIR No. 42. Washington, DC: USDA-Natural Resources Conservation Service.

Burt, R., Chiaretti, J. V., \& Prevost, D. J. (2005). Trace elements of selected soils in western Nevada and eastern California. Soil Survey Horizons, 46, 120-131.

Burt, R., Filmore, M., Wilson, M. A., Gross, E. R., Langridge, R. W., \& Lammers, D. A. (2001). Soil Properties of selected pedons on ultramafic rocks in Klamath Mountains, Oregon. Communications in Soil Science and Plant Analysis, 32(13\&14), 2145-2175.

Burt, R., Wilson, M. A., Keck, T. J., Dougherty, B. D., Strom, D. E., \& Lindahl, J. A. (2003a). Trace element speciation in selected smelter-contaminated soils in Anaconda and Deer Lodge Valley, Montana, USA. Advances in Environmental Research, 8/1, 51-67.

Burt, R., Wilson, M. A., Mays, M. D., \& Lee, C. W. (2003b). Major and trace elements of selected pedons in the USA. Journal of Environmental Quality, 32, 2109-2121.

Byers, H. G., Alexander, L. T., \& Holmes, R. S. (1935). The composition and constitution of the colloids of certain of the great groups of soils. Tech. Bull. No. 484. Washington, DC: US Department of Agriculture.

Cattle, J. A., McBratney, A. B., \& Minasny, B. (2002). Kriging method evaluation for assessing the spatial distribution of urban soil lead contamination. Journal of Environmental Quality, 31, 1576-1588.

Chaney, R. L., Brown, S. L., Angle, J. S., Stuczynski, T. I., Daniels, W. L., Henry, C. L., et al. (2000). In situ remediation/reclamation/restoration of metals contaminated soils using tailor-made biosolids mixtures. (In Proc Symposium on Mining, Forest and Land Restoration: The Successful Use of Residuals/Biosolids/Organic Matter for Reclamation Activities, Chp. 2, pp. 24, July 17-20, 2000). (Denver, CO: Rocky Mountain Water Environment Assoc.).

Chen, T., Huang, Z., Huang, Y., \& Lei, M. (2004). Distribution of arsenic and essential elements in pinna of arsenic hyperaccumlator Pteris vittata L. Science in China Series C Life Sciences, 48(1), 13-19.

Chen, M., Ma, L. Q., \& Harris, W. G. (1999). Baseline concentration of 15 trace elements in Florida surface soils. Journal of Environmental Quality, 28, 1173-1181.

Chen, M., Ma, L. Q., \& Harris, W. G. (2002). Arsenic concentration in Florida surface soils: Influence by soil type and properties. Soil Science Society of America Journal, 66, 632-640.
Chirenje, T., Ma, L. Q., Szulczewski, M., Littell, R., Portier, K. M., $\&$ Zillioux, E. (2003). Arsenic distribution in Florida urban soils: Comparison between Gainesville and Miami. Journal of Environmental Quality, 32, 109-119.

Ciolkosz, E. J., Amistadi, M. K., \& Thurman, N. C. (1993a). Metals in Pennsylvania soils. Agronomy Series No. 128. University Park, PA: Department of Agronomy, Pennsylvania State University.

Ciolkosz, E. J., Rose, A. W., Waltman, W. J., \& Thurman, N. C. (1993b). Total elemental analysis of Pennsylvania soils. Agronomy Series No. 126. University Park, PA: Department of Agronomy, Pennsylvania State University.

Ciolkosz, E. J., Stehouwer, R. C., \& Amistadi, M. K. (1998). Metal data for Pennsylvania soils. Agronomy Series No. 140. University Park, PA: Department of Agronomy, Pennsylvania State University.

Codling, E. E., \& Ritchie, J. C. (2005). Eastern gamagrass uptake of lead and arsenic from lead arsenate contaminated soil amended with lime and phosphorus. Soil Science, 170(6), 413-424.

Cong, T., \& Ma, L. Q. (2002). Arsenic accumulation in the Hyperaccumulator Chinese Brake and its utilization potential for phytoremediation. Journal of Environmental Quality, 31, 1671-1675.

Crock, J. G. (1996). Mercury. In D. L. Sparks, et al. (Eds.), Methods of soil analysis. Part 3: Chemical methods (pp. 769-791). Soil Sci. Soc. Am. Book Series No. 5. (Madison, WI: Soil Science Society of America).

D’Amore, J. J., Al-Abed, S. R., Scheckel, K. G., \& Ryan, J. A. (2005). Methods for speciation of metals in soils: A review. Journal of Environmental Quality, 34, 1707-1745.

Darmody, R. G., Marlin, J. C., Talbott, J., Green, R. A., Brewer, E. F., \& Stohr, C. (2004). Dredged Illinois River Sediments: Plant growth and metal uptake. Journal of Environmental Quality, 33, 458-464.

Darnley, A., Björklund, A., Bølviken, B., Gustavson, N., Koval, P. V., Plant, J. A., et al. (1995). A global geochemical database for environmental and resource management. Recommendations for international geochemical mapping. Earth Sciences Report 19. 122p. (Paris, France. UNESCO Publ.).

Denison, I. A. (1930). The chemical composition of colloidal material isolated from the horizons of various soil profiles. Journal of Agricultural Research, 40(5), 469-483.

Deverel, S. J., Gilliom, R. J., Fujii, R., Izbicki, J. A., \& Fields, J. C. (1984). Areal distribution of selenium and other inorganic constituents in shallow ground water of the San Luis Drain Service Area, San Joaquin Valley, California: A preliminary study. US Geol. Surv. Water Res. Invest. Rep. 84-4319. (Washington, DC: US Geol. Survey).

Esser, K. B., Hemke, P. A., \& Bockheim, J. G. (1991). Trace element contamination of soils in the Indiana dunes. Journal of Environmental Quality, 20, 492-496.

Evans, C. V., Fanning, D. S., \& Short, J. R. (2000). Humaninfluenced soils. In R. B. Brown et al. (Eds.), Managing soils in an urban environment (pp. 33-68). Agron. Monogr. 39. (Madison, WI: American Society of Agronomy).

Fendorf, S., La Force, M. J., \& Guangchao, L. (2004). Temporal changes in soil partitioning and bioaccessibility of Arsenic, Chromium, and Lead. Journal of Environmental Quality, 33, 2049-2055. 
Fio, J. L., Fujii, R., \& Deverel, S. J. (1991). Selenium mobility and distribution in irrigated and nonirrigated alluvial soils. Soil Science Society of America Journal, 55, 1313-1320.

Förstner, U. (1995). Land contamination by metals: global scale and magnitude of problem. In H. E. Allen, C. P. Huang, G. W. Bailey, \& A. R. Bowers (Eds.), Metal speciation and contamination of soil (pp. 1-33). Boca Raton, FL: Lewis Publishers.

Franklin, R. E., Duis, L., Smith, B. R., \& Toler, J. E. (2003). Elemental concentrations in soils of South Carolina. Soil Science, 168(4), 280-291.

Gambrell, R. P. (1994). Trace and toxic metals in wetlands - a review. Journal of Environmental Quality, 23, 883-891.

Garrett, R. G. (1994). The distribution of cadmium in A horizon soils in the prairies of Canada and adjoining United States. P. 73-82 In Current Research 1994-B. Geological Survey of Canada. Calgary, AB

Garrett, R. G., \& Thorleifson, L. H. (1991). Prairie kimberlite study-soil and till geochemistry and mineralogy, low density orientation survey traverses, Winnipeg-CalgaryEdmonton-Winnipeg. Geological Survey of Canada, Open File 2685.

Goldberg, S., Martens, D. A., Forster, H. S., \& Herbel, M. J. (2006). Speciation of selenium(IV) and selenium(VI) using coupled ion chromatography-hydride generation atomic absorption spectrometry. Soil Science Society of America Journal, 70, 41-47.

Gough, L. P., Kotra, R. K., Holmes, C. W., Griggs, P. H., Crock, J. G., Fey, D. L., et al. (1996). Chemical analysis results for mercury and trace elements in vegetation, water, and organic-rich sediments, south Florida. USGS Open File Report 96-091. Washington, DC: US Gov. Print. Office.

Gustin, M. S., Taylor, Jr., G. E., \& Leonard, T. L. (1994). High levels of mercury contamination in multiple media of the Carson River Drainage Basin of Nevada: Implications for risk assessment. Environmental Health Perspectives, 102 (9), 772-778.

Haluschak, P. W., Eilers, R. G., Mills, G. F., \& Grift, S. (1998). Status of selected trace elements in agricultural soils of southern Manitoba. Technical Report 1998-6E. Land Resource Unit, Brandon Research Centre, Research Branch, Agriculture and Agri-Food Canada.

Harris, W. G. (2002). Phosphate minerals. In J. B. Dixon \& D. G. Schultz (Eds.). Soil mineralogy with environmental applications (pp. 637-665). Soil Sci. Soc. Book Series No. 7. Madison, WI: Soil Science Society of America.

Heuvelink, G. B. M., \& Webster, R. (2001). Modeling soil variation: Past, present, and future. Geoderma, 100, 269301.

Holmes, R. S. (1928). Variations of the colloidal material in typical areas of the Leonardtown silt loam soil. Journal of Agricultural Research, 36(5), 459-470.

Holmes, R. S., Hearn, W. E., \& Byers, H. G. (1938). The chemical composition of soils and colloids of the Norfolk and related soil series. Tech. Bull. No. 594. Washington, DC: US Dept. Ag.

Holmgren, G. G. S., Meyer, M. W., Chaney, R. L., \& Daniels, R. B. (1993). Cadmium, lead, zinc, copper, and nickel in agricultural soils of the United States of America. Journal of Environmental Quality, 22, 335-348.
Houba, V. J. G., Lexmond, Th. M., Novozamsky, I., van der Lee, J. J. (1996). State of the art and future developments in soil analysis for bioavailability assessment. The Science of the Total Environment, 178, 21-28.

House, W. A., Hart, J. J., Norvell, W. A., \& Welch, R. M. (2003). Cadmium absorption and retention by rats fed durum wheat grain. British Journal of Nutrition, 89, 499-508.

Huang, P. M., \& Fujii, R. (1996). Selenium and arsenic. In D. L. Sparks, et al. (Eds.), Methods of soil analysis. Part 3: Chemical Methods (pp. 703-722). Soil Sci. Soc. Amer. Book Series No. 5. Madison, WI: Soil Science Society of America.

Illera, V., Garrido, F., Serrano, S., \& Garcia-Gonzalez, M. T. (2004). Immobilization of heavy metals $\mathrm{Cd}, \mathrm{Cu}$, and $\mathrm{Pb}$ in an acid soil amended with gypsum- and lime-rich industrial by-products. European Journal of Soil Science, 55, 135-145.

Indorante, S. J., McLeese, R. L., Hammer, R. D., Thompson, B. W., \& Alexander, D. L. (1996). Positioning soil survey for the 21 st century. Journal of Soil and Water Conservation, $51,21-28$.

Jenny, H. (1941). Factors of soil formation. New York: McGraw-Hill.

Jersak, J., Amundson, R., \& Brimhall, Jr., G. (1997). Trace metal geochemistry in Spodosols of the Northeastern United States. Journal of Environmental Quality, 26, 551-521.

Kabata-Pendias, A., \& Pendias, H. (2001). Trace elements in soils and plants (3rd ed.). Boca Raton, FL: CRC Press.

Kubota, J. (1964). Cobalt content of New England soils in relation to cobalt levels in forages for ruminant animals. Soil Science Society of America, 28, 246-251.

Kubota, J., Lazar, V. A., Langan, L. N., \& Beeson, K. C. (1961). The relationship of soils to molybdenum toxicity in cattle in Nevada. Soil Science Society of America, 25, 227-232.

Kubota, J., Lazar, V. A., Simonson, G. H., \& Hill, W. W. (1967). The relationship of soils to molybdenum toxicity in grazing animals in Oregon. Soil Science Society of America, 31, 667-671.

Kukier, U., \& Chaney, R. L. (2001). Amelioration of nickel phytotoxicity in muck and mineral soils. Journal of Environmental Quality, 30, 1949-1960.

Langley-Turnbaugh, S. J., Wilkinson, D., \& Rocque, D. (2005). Portland underground: Exploring urban soils in Maine. Soil Survey Horizons, 46, 1-13.

Lee, B. D., Graham, R. C., Laurent, T. E., Amrhein, C., \& Creasy, R. M. (2001). Spatial distributions of soil chemical conditions in a serpentinitic wetland and surrounding landscape. Soil Science Society of America Journal, 65, 1183-1196.

Leenhardt, D., Voltz, M., Bornand, M., \& Webster, R. (1994). Evaluating soil maps for prediction of soil water properties. European Journal of Soil Science, 45, 293-301.

Li, Y-M., Chaney, R. L., Schneiter, A. A., Miller, J. F., Elias, E. M., \& Hammond, J. J. (1997). Screening for low grain cadmium phenotypes in sunflower, durum wheat and flax. Euphytica, 94, 23-30.

Liao, X. Y., Chen, T. B., Xie, H., \& Liu, Y. R. (2005). Soil As contamination and its risk assessment in areas near the industrial districts of Chenzhou City, Southern China. Environment International, 31, 791-798. 
Lombi, E., Zhao, F. J., Dunham, S. J., \& McGrath, S. P. (2001). Phytoremediation of heavy metal-contaminated soils: Natural hyperaccumulation versus chemically enhanced phytoremediation. Journal of Environmental Quality, 30, 1919-1926.

Ma, L. Q., Tan, F., \& Harris, W. G. (1997). Concentrations and distributions of eleven metals in Florida soils. Journal of Environmental Quality, 26, 769-775.

Marbut, C. F. (1935). Soils of the United States. In O. E. Baker (Ed.), Atlas of American agriculture, physical basis. Part III (pp. 98). Washington, DC: US Department of Agriculture.

Markus, J. A., \& McBratney, A. B. (1996). An urban soil survey: Heavy metals in Glebe, Australia. Australian Journal of Soil Research, 34, 453-465.

Marques, J. J., Schulze, D. G., Curi, N., \& Mertzman, S. A. (2004). Trace element geochemistry in Brazilizan Cerrado soils. Geoderma, 121, 31-43.

Masscheleyn, P. H., Delaune, R. D., \& Patrick, Jr., W. H. (1991). Arsenic and selenium chemistry as affected by sediment redox potential and $\mathrm{pH}$. Journal of Environmental Quality, 20, 522-527.

McBratney, A. B., Odeh, I. O. A., Bishop, T. F. A., Dunbar, M. S., \& Shatar, T. M. (2000). An overview of pedometric techniques for use in soil survey. Geoderma, 97, 293-327.

McBride, M. B., Nibarger, E. A., Richards, B. K., \& Steenhuis, T. (2003). Trace metal accumulation by red clover grown on sewage sludge-amended soils and correlations to Mehlich3 and calcium chloride-extractable metals. Soil Science, 168(1), 29-38.

Mermut, A. R., Jain, J. C., Song, L., Kerrich, R., Kozak, L., \& Jana, S. (1996). Trace element concentrations of selected soils and fertilizers in Saskatchewan, Canada. Journal of Environmental Quality, 25, 845-853.

Mielke, H. W. (2005). Lead's toxic urban legacy and children's health. Geotimes, pp. 22-26, May issue.

Mielke, H. W., Anderson, J. C., Berry, K. J., Mielke, P. W., Chaney, R. L., \& Leech, M. (1983). Lead concentrations in inner-city soils as a factor in the child lead problem. American Journal of Public Health, 73(12), 1366-1369.

Mielke, H. W., Gonzales, C. R., Smith, M. K., \& Mielke, P. W. (1999). The urban environment and children's health: Soils as an integrator of lead, zinc, cadmium in New Orleans, Louisiana, USA. Environmental Research, 81, 117-129.

Mielke, H. W., Gonzales, C. R., Smith, M. K., \& Mielke, P. W. (2000). Quantities and associations of lead, zinc, cadmium, manganese, chromium, nickel, vanadium, and copper in fresh Mississippi delta alluvium and New Orleans alluvial soils. Science of the Total Environment, 246, 249-259.

Muhs, D. R., Bettis, III, E. A., Been, J., \& McGeehin, J. P. (2001). Impact of climate and parent material on chemical weathering in loess-derived soils of the Mississippi River Valley. Soil Science Society of America Journal, 65, 17611777.

Murray, K. S., Rogers, D. T., \& Kaufman, M. M. (2004). Heavy metals in an urban watershed in southeastern Michigan. Journal Environmental Quality, 33, 163-172.

Neuendorf, K. K. E., Mehl, Jr., J. P., \& Jackson, J. A. (Eds.) (2005). Glossary of geology (5th ed.). Washington, DC: American Geological Institute.

Nogawa, K, Yamada, Y., Honda, R., Ishizaki, M., Tsuritani, I., Kawano, S., et al. (1983). The relationship between itai- itai disease among inhabitants of the Jinzu River basin and cadmium in rice. Toxicology Letters, 17(3-4), 263-266.

Norvell, W. A., Wu, J., Hopkins, D. G., \& Welch, R. M. (2000). Association of cadmium in durum wheat grain with soil chloride and chelate-extractable soil cadmium. Soil Science Society of America Journal, 64, 2162-2168.

Pardue, J. H., DeLaune, R. D., \& Patrick, Jr., W. H. (1992). Metal to aluminum correlation in Louisiana coastal wetlands: Identification of elevated metal concentrations. Journal of Environmental Quality, 21, 539-545.

Pettry, D. E., \& Switzer, R. E. (1993). Heavy metal concentration in selected soils and parent materials in Mississippi. Bulletin 998., Starkville, MS: Office of Agr. Comm., Mississippi State Univ.

Pierzynski, G. M., \& Schwab, A. P. (1993). Bioavailability of zinc, cadmium, and lead in a metal-contaminated alluvial soil. Journal of Environmental Quality, 22, 247-254.

Pierzynski, G. M., Sims, J. T., \& Vance, G. F. (2000). Soils and environmental quality (2nd ed.). Boca Raton, FL: CRC Press.

Pietz, R. I., Vetter, R. J., Masarik, D., \& McFee, W. W. (1978). Zinc and cadmium contents of agricultural soils in corn in northwestern Indiana. Journal of Environmental Quality, 7, 381-385.

Plant, J., Smith, D., Smith, B., \& Williams, L. (2000). Environmental geochemistry at a global scale. Journal of the Geological Society, 157, 837-849.

Quantin, C., Becquer, T., Bouiller, J. H., \& Berthelin, J. (2002). Redistribution of metals in a New Caledonia Ferralsol after microbial weathering. Soil Science Society of America Journal, 66, 1797-1804.

Rabenhorst, M. C., \& Foss, J. E. (1981). Soil and geologic mapping over mafic and ultramafic parent materials in Maryland. Soil Science Society of America Proceedings, 45, 1156-1160.

Reed, S. T., \& Martens, D. C. (1996). Copper and Zinc. In D. L. Sparks, et al. (Eds.), Methods of soil analysis. Part 3: Chemical Methods (pp. 703-722). Soil Sci. Soc. Amer. Book Series No. 5. Madison, WI: Soil Sci. Soc. Am.

Reimann, C., Filzmoser, P., \& Garrett, R. (2005). Background and threshold: Critical comparison of methods of determination. Science of the Total Environment, 346, 1-16.

Reimann, C., Siewers, U., Tarvainen, T., Bityukova, L., Eriksson, J., Gilucis, A., et al. (2000). Baltic soil survey: Total concentrations of major and selected trace elements in arable soils from 10 countries around the Baltic Sea. Science of the Total Environment, 257(2-3), 155-170.

Renella, G., Adamo, P., Bianco, M. R., Landi, L., Violante, P., \& Nannipieri, P. (2004). Availability and speciation of cadmium added to a calcareous soil under various managements. European Journal of Soil Science, 55, 123-133.

Richardson, J. L., Arndt, J. L., \& Parker, W. B. (2001). Hydrology of wetland and related soils. In J. L. Richardson, \& M. J. Vepraskas (Eds.), Wetland soils: Genesis, hydrology, landscapes, and classification (p. 35-84). Boca Raton, FL: Lewis Publ.

Roberts, D., Nachtegall, M., \& Sparks, D. L. (2005). Speciation of metals in soils. In M. A. Tabatabai, \& D. L. Sparks (Eds.), Chemical processes in soils. Book Series No. 8. (p. 619-654). Madison, WI: Soil Science Society of America.

Romkens, P. F. A. M., \& Salomons, W. (1998). Cd, Cu, and Zn solubility in arable and forest soils: Consequences of land 
use changes for metal mobility and risk assessment. Soil Science, 163(11), 859-871.

Salminen, R., Batista, M. J., Bidovec, M., Demetriades, A., De Vivo, B., De Vos, W., et al. (2005). Geochemical Atlas of Europe. Part 1 - background information, methodology and maps. Retrieved April 23, 2007: http:/www.gsf.fi/ publ/foregsatlas/index.php.

Sauve, S., \& Parker, D. R. (2005). Chemical speciation of trace elements in soil solution. In M. A. Tabatabai \& D. L. Sparks (Eds.), Chemical processes in soils (pp. 655-688). Book Series No. 8. Madison, WI: Soil Sci. Soc. Am.

Senesi, N., \& Loffredo, E. (2005). Metal ion complexation by soil humic substances. In M. A. Tabatabai \& D. L. Sparks (Eds.), Chemical processes in soils (pp. 563-617). Book Series No. 8. Madison, WI: Soil Sci. Soc. Am.

Shacklette, H. T., \& Boerngen, J. G. (1984). Element concentrations in soils and other surficial materials of the conterminous United States. U.S. Geol Survey Professional Paper 1270. Washington, DC: U.S. Gov. Print. Office.

Sherman, G. D. (1952). The titanium content of Hawaiian soils and its significance. Soil Sci. Soc. Am. Proc., 16, 15-18.

Shuman, L. M. (2005). Chemistry of micronutrients in soils. In M. A. Tabatabai \& D. L. Sparks (Eds.), Chemical processes in soils (pp. 293-308). Book Series No. 8. Madison, WI: Soil Sci. Soc. Am.

Singh, B. R. (1997). Soil pollution and contamination. In R. Lal, et al. (Eds.), Advances in soil science: Methods for assessment of soil degradation (pp. 279-299). Boca Raton, FL: CRC Press.

Soil Science Society of America. (1997). Glossary of soil science terms. Madison, WI: Soil Science Society of America.

Soil Survey Division Staff. (1993). Soil survey manual. U.S. Dept. Agric. Handb. 18. Washington, DC: USDA-Soil Cons. Serv.

Soil Survey Staff. (1975). Soil taxonomy: A basic system of soil classification for making and interpreting soil surveys. USDA NRCS Agr. Handbook No. 436. Washington, DC: U.S. Govt. Print. Office.

Soil Survey Staff. (1999). Soil taxonomy: A basic system of soil classification for making and interpreting soil surveys (2nd ed.). USDA NRCS Agr. Handbook No. 436. Washington, DC: U.S. Gov. Print. Office.

Soil Survey Staff. (2006). Keys to soil taxonomy (10th ed.). Washington, D.C: U.S. Gov. Print. Office.

Sommer, M., Halm D., Weller, U., Zarei, M, \& Star, K. (2000). Lateral podzolization in a granitic landscape. Soil Science Society of America Journal, 64, 1434-1442.

Sposito, G. (1989). The chemistry of soils. New York: Oxford Univ. Press.

Steinnes, E., Sjobakk, T. E., Donisa, C., \& Brannvall, M. L. (2005). Quantification of pollutant lead in forest soils. Soil Science Society of America Journal, 69, 1399-1404.

Stewart, M. A., Jardine, P. M., Barnett, M. O., Mehlhorn, T. L., Hyder L. K., \& McKay, L. D. (2003). Influence of soil geochemical and physical properties on the sorption and bioaccessibility of Chromium (III). Journal of Environmental Quality, 32, 129-137.
Strawn, D., Doner, H., Zavarin, M., \& McHugo, S. (2002). Microscale investigation into the geochemistry of arsenic, selenium, and iron in soil developed in pyritic shale materials. Geoderma, 108, 237-257.

Takeda, A., Kimura, K., \& Yamasaki, S. (2004). Analysis of 57 elements in Japanese soils, with special reference to soil group and agricultural use. Geoderma, 119, 291-307.

Taylor, H. E., Antweiler, R. C., Roth, D. A., Brinton, T. I., Peart, D. B., \& Healy, D. F. (2001). The occurrence and distribution of selected trace elements in the Upper Rio Grande and tributaries in Colorado and Northern New Mexico. Environmental Contamination and Toxicology, 41, 410-426.

Tessier, A., Campbell, P. G. C., \& Bisson, M. (1979). Sequential extraction procedure for the speciation of particulate trace metals. Analitical Chemistry, 51, 844-851.

Tugel, A. J., Herrick, J. E., Brown, J. R., Mausbach, M. J., Puckett, W., \& Hipple, K. (2005). Soil change, soil survey, and natural resources decision making: A blueprint for action. Soil Science Society of America Journal, 69, 738-747.

US Department of Agriculture, Natural Resources Conservation Service. (2005a). National soil survey handbook, title 430-VI. Retrieved April 23, 2007: http://soils.usda.gov/ technical/handbook.

US Department of Agriculture, Natural Resources Conservation Service. (2005b). Stream corridor restoration. Washington, DC: US Dept. Commerce, National Tech. Info. Serv.

Upchurch, D. R., \&. Edmonds, W. J. (1991). Statistical procedures for specific objectives. In M. J. Mausbach \& L. P. Wilding (Eds.), Spatial variabilities of soils and landforms (pp. 49-71). SSSA Spec. Pub. No. 28, Madison, WI: Soil Sci. Soc. Am.

Waldman, P. (2005). Mercury and Tuna: US Advice Leaves Lots of Questions. Wall Street Journal, Aug. 1, 2005.

Wilcke, W., \& Amelung, W. (1996). Small-scale heterogeneity of aluminum and heavy metals in aggregates along a climatic transect. Soil Sci. Soc. Am. Proc., 60, 1490-1495.

Wilson, M. A., Burt, R., \& Mays, M. D. (2002, October). The geochemical analysis program in the USDA-NRCS soil survey laboratory. (Paper presented at the USDA Nat. Res. Cons. Serv. State Soil Scientists Meeting. St. Joseph, MO.)

Wu, J., Norvell, W. A., Hopkins, D. G., \& Welch, R. M. (2002). Spatial variability of grain Cadmium and soil characteristics in a Durum wheat field. Soil Science Society of America Journal, 66, 268-275.

Xie, X., \& Yin, B. (1993). Geochemical patterns from local to global. Journal of Geochemical Exploration, 47, 109-129.

Yaalon, D. H., \& Yaron, B. (1966). Framework for man-made soil changes: An outline of metapedogenesis. Soil Science, 102, 272-277.

Yang, J. K., Barnett, M. O., Jardine, P. M., Basta, N. T., \& Casteel, S. W. (2002). Adsorption, sequestration, and bioaccessibility of $\mathrm{As}(\mathrm{V})$ in soils. Environmental Science and Technology, 36, 4562-4569. 